\title{
Geologic characterization of nonconformities using outcrop and core analogs: hydrologic implications for injection-induced seismicity
}

\author{
Elizabeth S. Petrie ${ }^{1}$, Kelly K. Bradbury ${ }^{2}$, Laura Cuccio ${ }^{2}$, Kayla Smith ${ }^{2}$, James P. Evans ${ }^{2}$, John P. Ortiz ${ }^{4}$, \\ Kellie Kerner ${ }^{3}$, Mark Person ${ }^{3}$, and Peter Mozley ${ }^{3}$ \\ ${ }^{1}$ Western Colorado University, Geology Department, 1 Western Way, Gunnison, CO 81231, USA \\ ${ }^{2}$ Utah State University, Geology Department, 4505 Old Main Hill, Logan, UT 84322-4505, USA \\ ${ }^{3}$ New Mexico Institute of Mining and Technology, 801 Leroy Pl., Socorro, NM 87801, USA \\ ${ }^{4}$ Johns Hopkins University, Department of Environmental Health and Engineering, \\ 3400 N. Charles St., Baltimore, MD 21218, USA
}

Correspondence: Elizabeth Petrie (epetrie@western.edu)

Received: 12 February 2020 - Discussion started: 26 March 2020

Revised: 25 June 2020 - Accepted: 8 July 2020 - Published: 12 October 2020

\begin{abstract}
The occurrence of induced earthquakes in crystalline rocks kilometers from deep wastewater injection wells poses questions about the influence nonconformity contacts have on the downward and lateral transmission of pore-fluid pressure and poroelastic stresses. We hypothesize that structural and mineralogical heterogeneities at the sedimentarycrystalline rock nonconformity control the degree to which fluids, fluid pressure, and associated poroelastic stresses are transmitted over long distances across and along the nonconformity boundary. We examined the spatial distribution of physical and chemical heterogeneities in outcrops and core samples of the Great Unconformity in the midcontinent of the United States, capturing a range of tectonic settings and rock properties that we use to characterize the degree of past fluid communication and the potential for future communication. We identify three end-member nonconformity types that represent a range of properties that will influence direct fluid pressure transmission and poroelastic responses far from the injection site. These nonconformity types vary depending on whether the contact is sharp and minimally altered (Type 0), dominated by phyllosilicates (Type I), or secondary non-phyllosilicate mineralization (Type II). Our observations provide geologic constraints for modeling fluid migration and the associated pressure communication and poroelastic effects at large-scale disposal projects by providing relevant subsurface properties and much needed data regarding common alteration minerals that may interact readily with brines or reactive fluids.
\end{abstract}

\section{Introduction}

Deep wastewater injection near the nonconformity between the Phanerozoic sedimentary sequence and Proterozoic crystalline basement in the midcontinent United States (Sloss, 1963) is the primary means by which produced formation fluids are disposed of in Class II injection wells (Murray, 2015). Increased rates of seismicity in this region are associated with large volumes of wastewater injection (Ellsworth et al., 2015; Keranen et al., 2013; Nicholson and Wesson, 1990; Petersen et al., 2016; Zhang et al., 2013); the reduction of friction on preexisting faults and pressure diffusion away from the injection point are controlled by the permeability structure of the rocks in the subsurface (Goebel and Brodsky, 2018; Yehya et al., 2018). Recent midcontinent seismicity nucleates on faults in crystalline rocks kilometers from injection sites (Keranen et al., 2014; Weingarten et al., 2015; Zhang et al., 2016) and spans timescales of months to years post-injection, indicating that pore-fluid pressures and/or poroelastic loads are transmitted across or along the nonconformity or through connected fracture systems (including joints, faults, and veins) in the crystalline rocks (Ortiz et al., 2019). The depths of seismicity (up to $11 \mathrm{~km}$ ) at some injection sites suggest that crystalline basement permeability is perhaps moderate to high $\left(10^{-16}\right.$ to $\left.10^{-14} \mathrm{~m}^{2}\right)$ (Zhang et al., 2016) and is dynamically increased by elevated fluid pressures (Rojstaczer, 2008). The observations presented in this paper are also relevant to Class VI injec- 
tion wells used for the geologic sequestration of $\mathrm{CO}_{2}$; several of our analog sites include deep reservoirs being evaluated for $\mathrm{CO}_{2}$ sequestration (Leetaru et al., 2009; Leetaru and McBride, 2009; Plains CO2 Reduction (PCOR) Partnership, 2020; Thorleifson, 2008).

Numerical modeling of fluid flow and/or loading stresses associated with poroelastic effects across nonconformities indicate that (1) the presence of a high-storativity, lowpermeability basal seal reduces the potential for basementinduced earthquakes; (2) poroelastic effects can trigger seismicity far away from the injection location; (3) the presence of conductive faults, including those that cut the nonconformity and those that are isolated in the basement, can provide direct fluid or fluid pressure pathways; and (4) permeable cross-nonconformity faults may exhibit high rates of seismicity (Chang and Segall, 2016; Goebel and Brodsky, 2018; Ortiz et al., 2019; Yehya et al., 2018; Zhang et al., 2013).

In this paper we summarize geologic observations made at the nonconformity zone, the altered rock volume surrounding the nonconformable contact. This zone varies in thickness and is defined by mineralogic and structural alteration of the protolith rocks surrounding the nonconformity. We characterize nonconformity zones associated with Precambrian granite, gabbro, gneiss, and schists that are overlain by porous sedimentary rocks including sandstone and mixed carbonate-clastic sequences. Study site locations were chosen based on their distribution within the midcontinent region and the suite of lithologies present (Fig. 1). These analogs represent the diversity of the nonconformity in the United States midcontinent region and are analogs for deep fluid injection from produced waters (Class II) and sequestration of $\mathrm{CO}_{2}$ (Class VI). At each site we document the lithology and structural features of the rocks on either side of the nonconformity to characterize the range of rock types associated with the contact and identify any evidence of past crosscontact fluid flow. We present data on the mineralogic and structural heterogeneities observed in the outcrop and core, and these observations serve as proxies for variation in mineral alteration and deformation surrounding subsurface nonconformity zones, which may impact the future migration of fluids along and across the contact.

We find three end-member types of nonconformity zones. These zones range from diffuse to sharp (Type 0), can be phyllosilicate-rich (Type I), or can be dominated by nonphyllosilicate secondary minerals (Type II). Each contact type observed in this study has a range of mineralized textures and structural discontinuities. Due to weathering, deformation, diagenesis, and fluid-rock interactions, the nonconformity zone may be hydraulically heterogeneous at scales of millimeters to tens of meters and influence the migration of fluid and fluid pressures away from the injection well. Characterizing variations in rock properties at the nonconformity zone is critical for safe implementation of deep fluid injection, as the dimensions and hydraulic properties of the rocks in the nonconformity zones impact the subsurface flow regimes (Ortiz et al., 2019). The lithologic character of the nonconformity zone has implications for hydraulically connected regions by allowing direct fluid communication, changes in pore-fluid pressure, and/or poroelastic loads. Because pressure diffusion and fluid migration depend on the permeability structure at a given location, our work can be used to improve hydrogeologic models that test the impact of lithologic changes and cross-nonconformity fractures on the transmission of pore fluids and/or poroelastic stress. We present results from hydrogeologic models based on observations of nonconformity zone characteristics, thereby testing the impact various nonconformity zone types have on the transmission of pore fluids.

\section{Geologic setting}

The North American craton, Laurentia, includes the Precambrian shields, the platforms and basins of the North American interior, and the reactivated Cordilleran foreland of the southwestern United States (Fig. 1). The craton includes Archean blocks, the Yavapai-Mazatzal and Grenville accretionary belts, and failed rifts (Hoffman, 1988; Marshak et al., 2017; Whitmeyer and Karlstrom, 2007). Precambrian exhumation produced erosional surfaces on the top of the crystalline basement, which were buried by Phanerozoic clastic and marine sedimentary rocks (Marshak et al., 2017; Sloss, 1988). The nonconformities studied in this paper are located within the Superior craton, an Archean basement complex of granite-greenstone or higher-grade equivalent overlain by erosional remnants of early Proterozoic platform facies (Hoffman, 1988), the Yavapai-Mazatzal province, 1.76$1.65 \mathrm{Ga}$ juvenile arc terrane that includes the Central Plains Orogen (Karlstrom and Humphreys, 1998; Sims, 1985; Sims and Peterman, 1986), the Grenville province, 1.3-1.0 Ga imbricate thrust slices formed during continent-continent collision (Rivers, 1997), and the Midcontinent Rift, an approximately $1.1 \mathrm{Ga}$ failed rift system dominated by volcanic rocks and basin-fill sedimentary rocks (Ojakangas et al., 2001) (Fig. 1).

\subsection{Study areas}

\subsubsection{Outcrop locations}

Exposed at Presque Isle and Hidden Beach along the southern shore of Lake Superior, Michigan, the nonconformity is defined by Proterozoic Jacobsville Sandstone overlying early Proterozoic altered peridotite crystalline basement (Fig. 2). The geologic history of the serpentinized peridotite is not well-constrained; it is thought that the peridotite was serpentinized between 1.80 and 1.1 Ga (Gair and Thaden, 1968). The overlying Jacobsville Sandstone is a dominantly fluvial sequence of feldspathic and quartzose sandstones (Malone et al., 2016), and at this study locality it consists of a variably indurated pebble to cobble conglomerate and a lentic- 


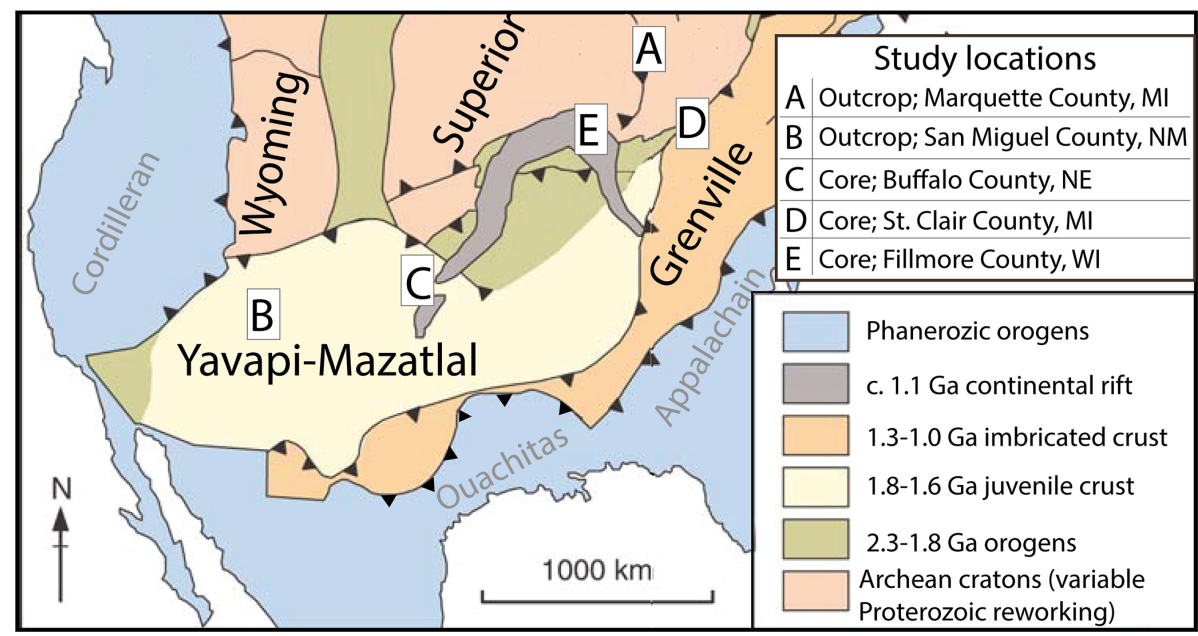

Figure 1. Precambrian tectonic elements map with the location of the nonconformity analog study sites (after St. Onge et al., 2009). (a) Lake Superior, Presque Isle, Michigan outcrop, (b) Gallinas Canyon, New Mexico outcrop, (c) R.C. Taylor 1 core, (d) CPC BD-139 core, and (e) BO-1 core.

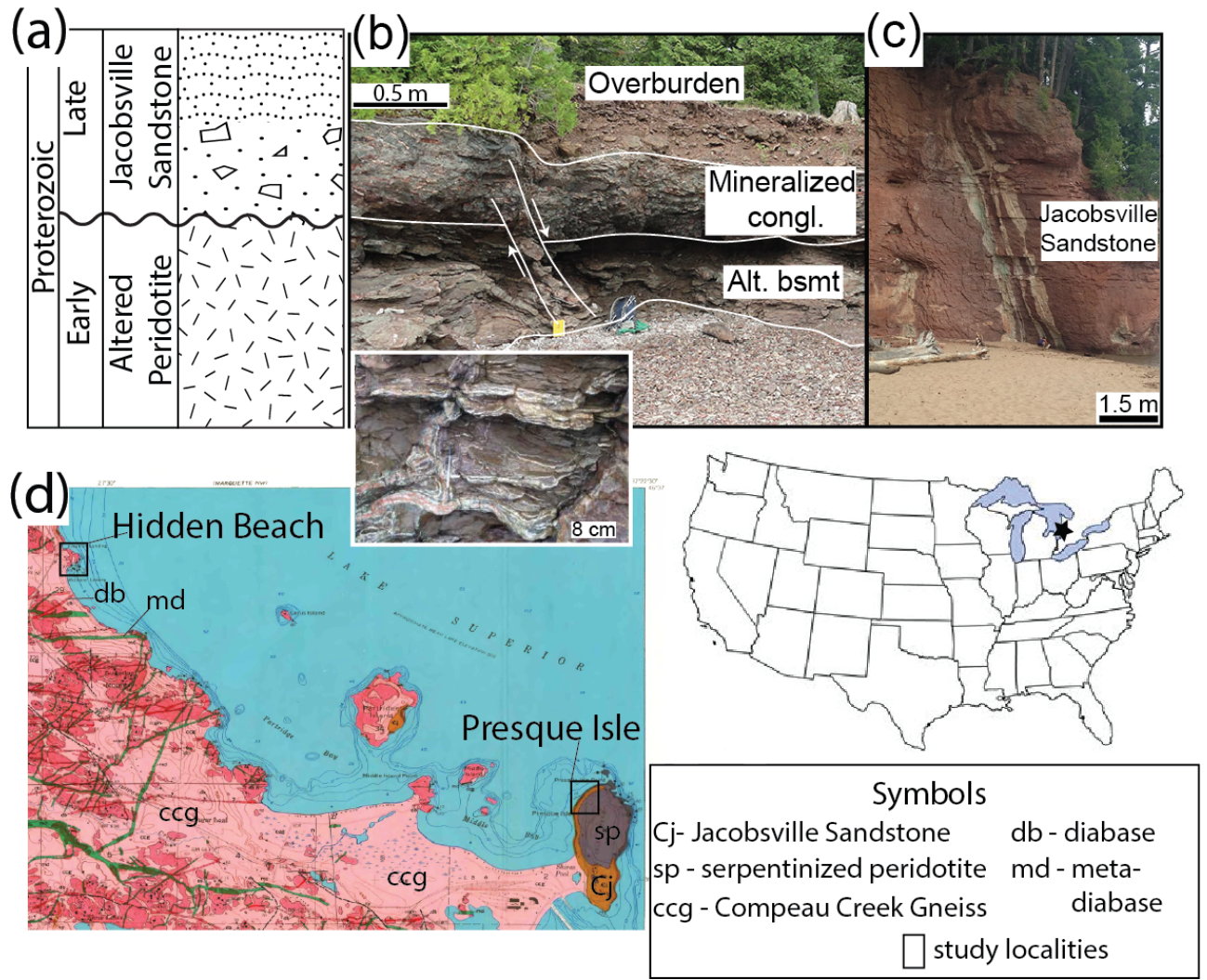

Figure 2. (a) Schematic lithologic log at Lake Superior, Michigan, where altered peridotite is overlain by the Jacobsville Sandstone at Presque Isle and mineralized conglomerates of the Jacobsville Sandstone overlie the Compeau gneiss at Hidden Beach. (b) Presque Isle outcrop of small fault cutting the contact between the mineralized conglomerate of the Jacobsville Sandstone and the underlying altered basement; the inset shows stockwork jasperoid veins in the underlying serpentinized peridotite basement and (c) Hidden Beach outcrops. At this locality the Jacobsville Sandstone overlies the Proterozoic altered peridotite basement rocks. (d) Geologic map of the Marquette, Michigan, field area showing the locations of Hidden Beach and Presque Isle; modified from Gair and Thaden (1968). 
ular planar to cross-bedded light red quartz arenite (Fig. 2). The Presque Isle outcrops are analogs for geologic sequestration of $\mathrm{CO}_{2}$ in the deep saline Jacobsville Sandstone reservoir (Leetaru and McBride, 2009).

The nonconformity at Gallinas Canyon is exposed along a $4 \mathrm{~km}$ long section in the southernmost Sangre de Cristo Mountains, New Mexico (Figs. 1 and 3). The outcrop exposure consists of the crystalline rocks of the Yavapai province, highly deformed compositionally layered quartzofeldspathic gneiss, amphibolitic gneiss, felsite, biotite schist, and granitic pegmatite (Lemen et al., 2015) overlain by the Devonian to Mississippian shallow marine transgressive sequence of carbonate and clastic rocks of the Espiritu Santo Formation. The Espiritu Santo Formation primarily consists of limestone and dolomitic limestone, with a basal conglomeratic sandstone known as the Del Padre Member (Baltz and Myers, 1999). The rocks are exposed within north-trending fault-bounded blocks uplifted during the Neogene Laramide Orogeny (Baltz and Myers, 1999; Lessard and Bejnar, 1976). This location provides an analog for the Raton Basin to the east where injection in Class II wells has been linked to basement earthquakes that began in 2001 (Nakai et al., 2017; Rubinstein et al., 2014).

\subsubsection{Core samples}

The R.C. Taylor 1 core samples the Cambrian La Motte Formation sandstone and sheared Proterozoic granitoids in the Central Plains Orogen of the 1.6 Ga Yavapai-Mazatzal province (Marshak et al., 2017; Sims, 1985; Whitmeyer and Karlstrom, 2007) (Fig. 1). The borehole was drilled adjacent to the Cambridge Arch and is associated with a series of northwest-trending transpressional faults of the Central Plains Orogen (Sims, 1985; Whitmeyer and Karlstrom, 2007) (Fig. 4). In this core, the arkosic La Motte Formation, regionally called the Reagan and Sawatch sandstones, is a fine-grained, well-sorted glauconitic sandstone deposited during a transgression and is an analog for Cambrian sandstones being evaluated for sequestration of $\mathrm{CO}_{2}$ (Carr et al., 2005; Miller, 2012).

The CPC BD-139 core, recovered from the Michigan Basin, samples the contact between the Cambrian Mount Simon Sandstone and Precambrian altered granitoid gneiss of the Grenville Front Tectonic Zone (Figs. 1 and 5). The Precambrian crystalline rocks captured in this core are characterized as granitic to tonalitic gneiss (Easton and Carter, 1995) that form the basement of the Michigan Basin. The Michigan Basin is a thermally complex intracratonic basin situated over the lower peninsula of Michigan. Unexpectedly high levels of thermal maturity in the Paleozoic strata of the basin are thought to be attributed to elevated basal heat flow occurring up until Silurian time and the prior existence of $\sim 2 \mathrm{~km}$ of Pennsylvanian and Permian strata that has since been eroded (Everham and Huntoon, 1999). The Mount Simon Sandstone reservoir is a unit of deep wastewater injec- tion in Oklahoma, and it is also targeted for $\mathrm{CO}_{2}$ storage (Barnes et al., 2009; Dewers et al., 2014; Leetaru et al., 2009; Liu et al., 2011).

The BO-1 core samples the lower Cambrian Mount Simon Sandstone overlying a Precambrian layered intrusive complex of altered gabbro and other mafic intrusions and felsic dikes (Fig. 6) (Smith et al., 2019). The crystalline basement rocks are part of the Northeast Iowa Intrusive Complex and are associated with the Midcontinent Rift system (Anderson, 2012). The Midcontinent Rift system extends from Kansas to Lake Superior and then southward through Michigan (Fig. 1). The geologic features associated with the Midcontinent Rift system, include axial basins filled with basalt and immature clastic rocks along with evidence of crustal extension (Ojakangas et al., 2001). The BO-1 core is analogous to several geologic settings anticipated in the subsurface of the midcontinent region where lower Cambrian rocks directly overly Precambrian mafic igneous rocks of the Midcontinent Rift system along the Great Unconformity (Gilbert, 1962; Mossler, 1995). Northwest-trending fault systems near the borehole were identified by magnetic lineaments and are likely part of the regional NW-SE Belle Plaine Fault Zone (Drenth et al., 2015). The Midcontinent Rift system is being studied for deep injection of $\mathrm{CO}_{2}$ (Abousif, 2015; Wickstrom et al., 2010).

\section{Characterization of the nonconformity}

Given the recognized importance of direct fluid transmission, variation in pressure, and poroelastic loads on induced seismicity (Chang and Segall, 2016; Ortiz et al., 2019; Yehya et al., 2018; Zhang et al., 2013), we provide an overview of rock properties observed at the nonconformity using integrated outcrop-based studies in Michigan and New Mexico, as well as analyses of cores from Michigan, Minnesota, and Nebraska (Fig. 1).

\subsection{Methods}

To describe the nonconformity zone in the core and outcrop and document structures and mineralogy across the boundary, we use a variety of microscale to mesoscale methods including lithological and structural logging of outcrop and core, optical thin-section petrography and X-ray diffraction (XRD) mineralogic studies, whole-rock X-ray fluorescence (XRF) elemental analysis, and gas or air permeability measurements, when possible. We evaluated fracture distribution in the outcrop and core, noting fracture types, the presence of fault and/or shear zones, and associated mineralogy. XRD and XRF were carried out at Utah State University (USU); XRD analysis was carried out at the Western Colorado University (WCU) petrography laboratory. At USU, XRD analyses were done using a Panalytical X'Pert Pro X-ray diffraction spectrometer $(40 \mathrm{~mA}$ and $45 \mathrm{kV})$ with 

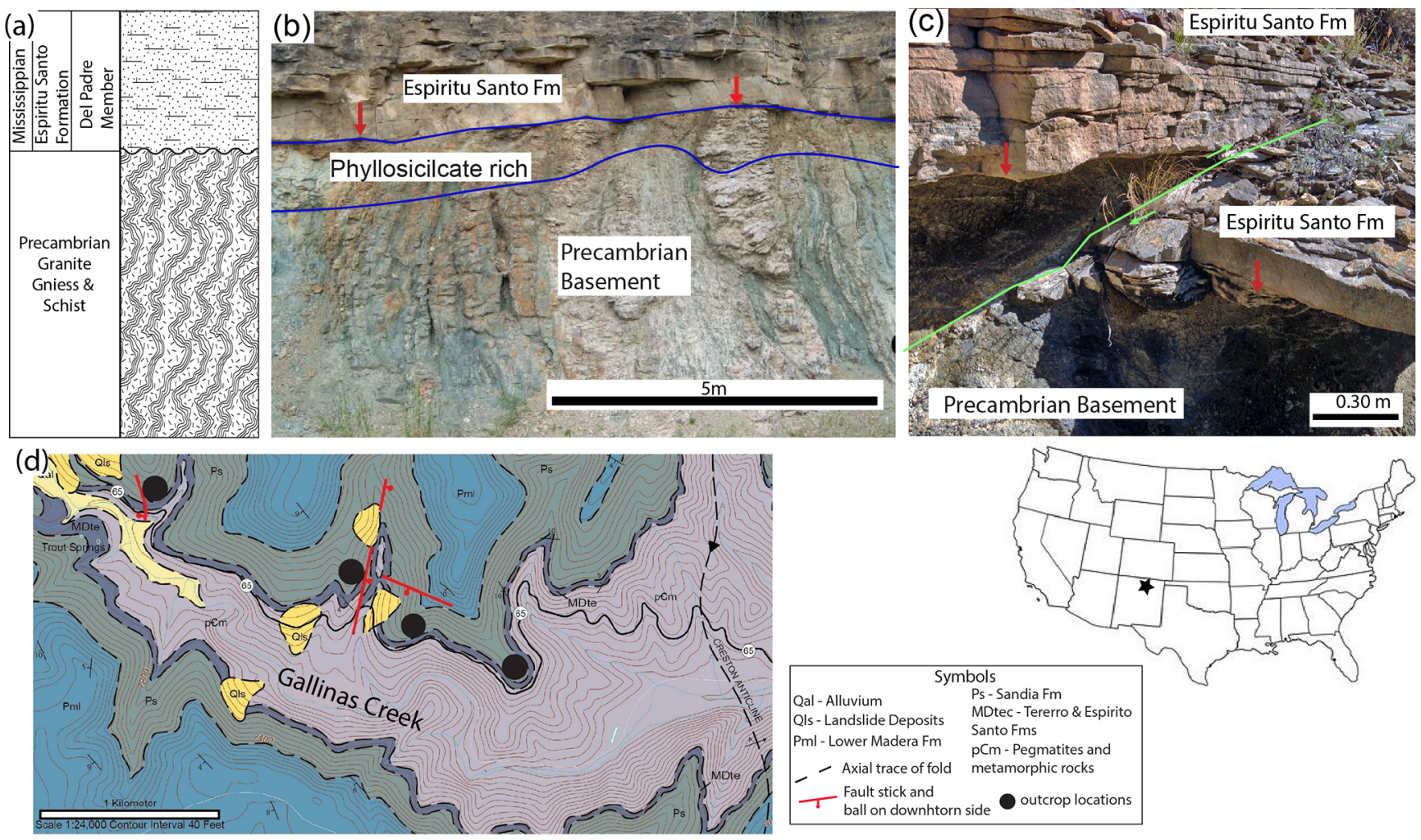

Figure 3. (a) Gallinas Canyon, New Mexico, outcrop lithology log. (b) Precambrian granitic gneiss and schist are overlain by the Mississippian Espiritu Santo Formation; red arrows mark the nonconformity, and blue lines mark the boundary of phyllosilicate alteration. (c) The $4 \mathrm{~km}$ long exposure in Gallinas Canyon; the nonconformity is cut by several centimeter to meter displacement faults. Red arrows mark the nonconformity, and the fault is shown by the green line. (d) Geologic map of the Gallinas Canyon study area; modified from Hesseltine (2019). Faults that cut the nonconformity are shown in red with a ball on the downthrown side; at the map scale the nonconformity is relatively planar and parallels topographic contour lines.

monochromatic $\mathrm{CuK} \alpha$ radiation utilizing X'Pert Highscore software for phase analysis. Whole-rock XRF analyses were conducted at the Washington State University Peter Hooper GeoAnalytical Lab using a Thermo-ARL automated X-ray fluorescence spectrometer. At WCU, XRD analysis was done using a Brucker D8 X-ray diffraction spectrometer (40 mA and $45 \mathrm{kV}$ ) with monochromatic $\mathrm{CuK} \alpha$ radiation utilizing DIFFRAC.SUITE software for phase analysis.

A total of 25 samples from the BO-1 drill core were selected for gas permeability testing through Schlumberger Rock Mechanics and Core Analysis Services. Profile permeability measurements were made in steady-state conditions with a mini-permeameter whereby gas is injected directly onto the core slab surface. The profile permeameter has a measurable permeability range of $0.1 \mathrm{mD}$ to $3 \mathrm{D}$ $\left(\sim 9.9 \times 10^{-17}\right.$ to $\left.3.0 \times 10^{-12} \mathrm{~m}^{2}\right)$.

To illustrate the effects of reduced permeability above the nonconformity on fluid migration we compare three hydrogeologic models of basal reservoir injection that consider continuous and discontinuous zones of altered lowpermeability rocks above the basement. We develop threedimensional models to assess fluid migration along crys- talline basement faults using MODFLOW, a public domain finite-difference groundwater flow code (Harbaugh and McDonald, 1996; Harbaugh et al., 2000) that solves the following groundwater equation:

$$
\begin{aligned}
& \frac{\partial}{\partial x}\left(K_{x} \frac{\partial h}{\partial x}\right)+\frac{\partial}{\partial y}\left(K_{y} \frac{\partial h}{\partial y}\right)+\frac{\partial}{\partial z}\left(K_{z} \frac{\partial h}{\partial z}\right) \\
& =S_{\mathrm{s}} \frac{\partial h}{\partial t}+Q(x, y, z, t),
\end{aligned}
$$

where $h$ is the hydraulic head (L), $K$ is the hydraulic conductivity tensor $\left(\mathrm{L} \mathrm{T}^{-1}\right), S_{\mathrm{s}}$ is the specific storage $\left(\mathrm{L}^{-1}\right), Q$ is the fluid injection source term (i.e., injection well; $\mathrm{T}^{-1}$ ), and $t$ is time (T). Equation (1) represents single-phase, constantdensity groundwater flow in a three-dimensional Cartesian coordinate system. Hydraulic conductivity is a lumped parameter that includes the influence of fluid and medium properties and is defined as $K=k r_{\mathrm{f}} g\left(\mathrm{~m}^{-1}\right)$, where $K$ is hydraulic conductivity $\left(\mathrm{m} \mathrm{s}^{-1}\right), k$ is intrinsic permeability $\left(\mathrm{m}^{2}\right)$, $r_{\mathrm{f}}$ is fluid density $\left(997 \mathrm{~kg} \mathrm{~m}^{-3}\right.$; water), $g$ is the acceleration due to gravity $\left(9.81 \mathrm{~m} \mathrm{~s}^{-2}\right)$, and $m$ is the dynamic viscosity of the fluid $\left(8.9 \times 10^{-4} \mathrm{~kg}\left(\mathrm{~m} \mathrm{~s}^{-1}\right)^{-1}\right)$. Multiple researchers have implemented similar groundwater flow mod- 
(a)

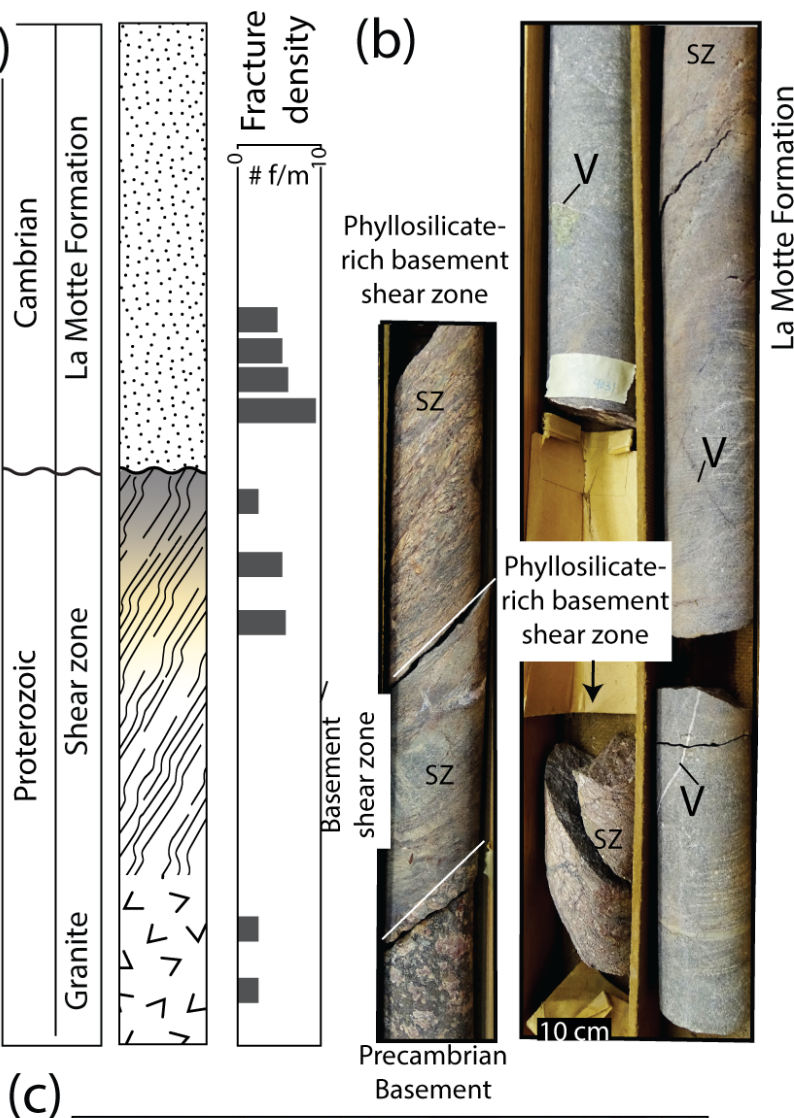

(c)

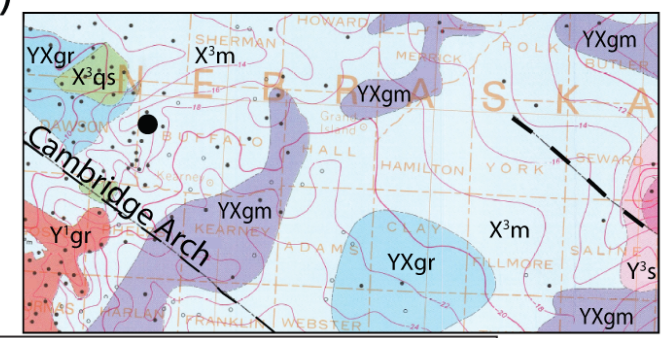

Symbols

$\mathrm{Y}^{3} \mathrm{~S}$ - Rocks of the Midcontinent Rift system YXgm - Magnetite-bearing granitoid rocks

YXgr - Mesozonal granitoid rocks

$X^{3} q$ - Quartzite

$\mathrm{X}^{3} \mathrm{~m}$ - Metamorphic rocks undivided

- Trend of Borehole

magnetic anolmaly

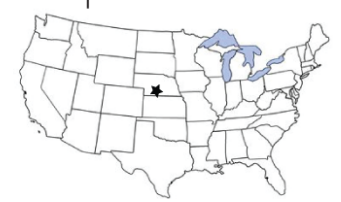

Figure 4. (a) Lithologic log of the R.C. Taylor 1 core, Nebraska, from 3984 to $4038 \mathrm{ft}$ (1214-1231 m) of measured depth. The nonconformity occurs at $4018 \mathrm{ft}(1225 \mathrm{~m})$. Fracture density in the core is based on the number of fractures per meter of core. Four lithologic units are identified in the core, including sandstone, sedimentary-rock-hosted shear zone, altered basement shear zone, and minimally altered basement. The nonconformity occurs between the altered basement shear zone and overlying sandstone of the La Motte Formation. (b) Photographs of the R.C. Taylor 1 core. Both the basement shear zone (SZ) and overlying sandstone are cut by veins (V) of quartz, calcite, and Fe-oxides. (c) The borehole location is shown on the Precambrian basement map from Sims (1985).

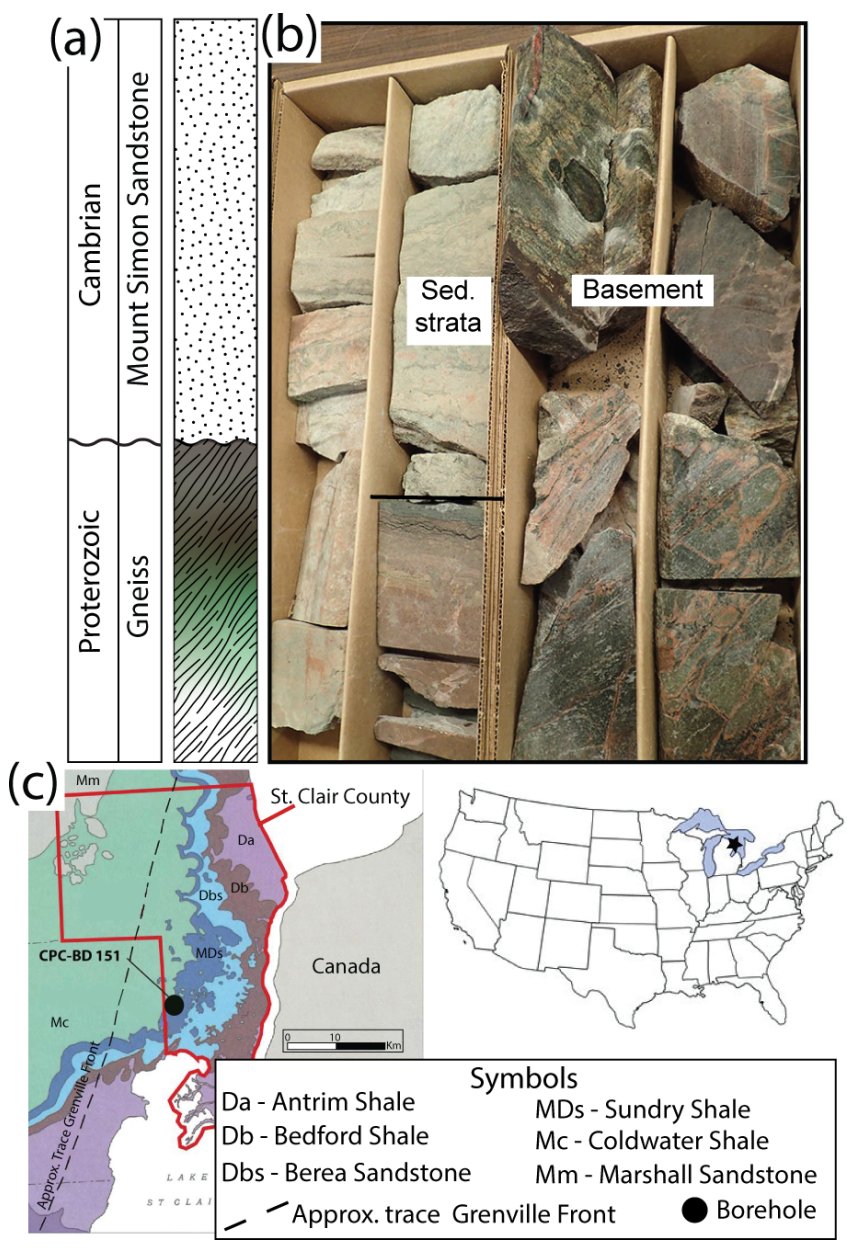

Figure 5. (a) Lithologic log of the CPC BD-139 core, Michigan, from 1404-1412.1 $\mathrm{m}$ of measured depth. There are five main lithologic units identified, including sandstone, dolomitized and undolomitized finely foliated gneiss, and dolomitized and undolomitized gneiss with subhorizontal white veins. (b) Photographs of the CPC BD-139 core showing the core between $\sim 1404.5$ and $1405.5 \mathrm{~m}$ as well as contact between the Cambrian Mount Simon Sandstone (light tan) and the underlying Precambrian gneiss. The gneiss directly at the contact is fine-grained, tan, and dolomitized. This is underlain by green altered gneiss with subvertical pink fractures. This lithology grades into a dark grey gneiss with subhorizontal white veins (core between 1411.5 and $1412.5 \mathrm{~m}$ ), which extends through the bottom of the logged section. (c) Geologic map St. Clair County, Michigan; modified from Milstein (1987).

els in MODFLOW to investigate pore pressure propagation associated with basal reservoir injection (Zhang et al., 2013, 2016), and a more exhaustive description of cases and boundary conditions can be found in Ortiz et al. (2019). Each of our model simulations includes a $100 \mathrm{~m}$ thick basal reservoir $\left(3 \times 10^{-15} \mathrm{~m}^{2}\right)$ underlain by $9.9 \mathrm{~km}$ of relatively lowpermeability $\left(k_{x}=k_{z}=3 \times 10^{-17} \mathrm{~m}^{2}\right)$ crystalline basement rock. A $20 \mathrm{~m}$ wide conduit-barrier fault $\left(k_{z} / k_{x}=105 ; k_{z}=\right.$ $\left.3 \times 10^{-10} \mathrm{~m}^{2}\right)$ is present in all simulations as is an injection 


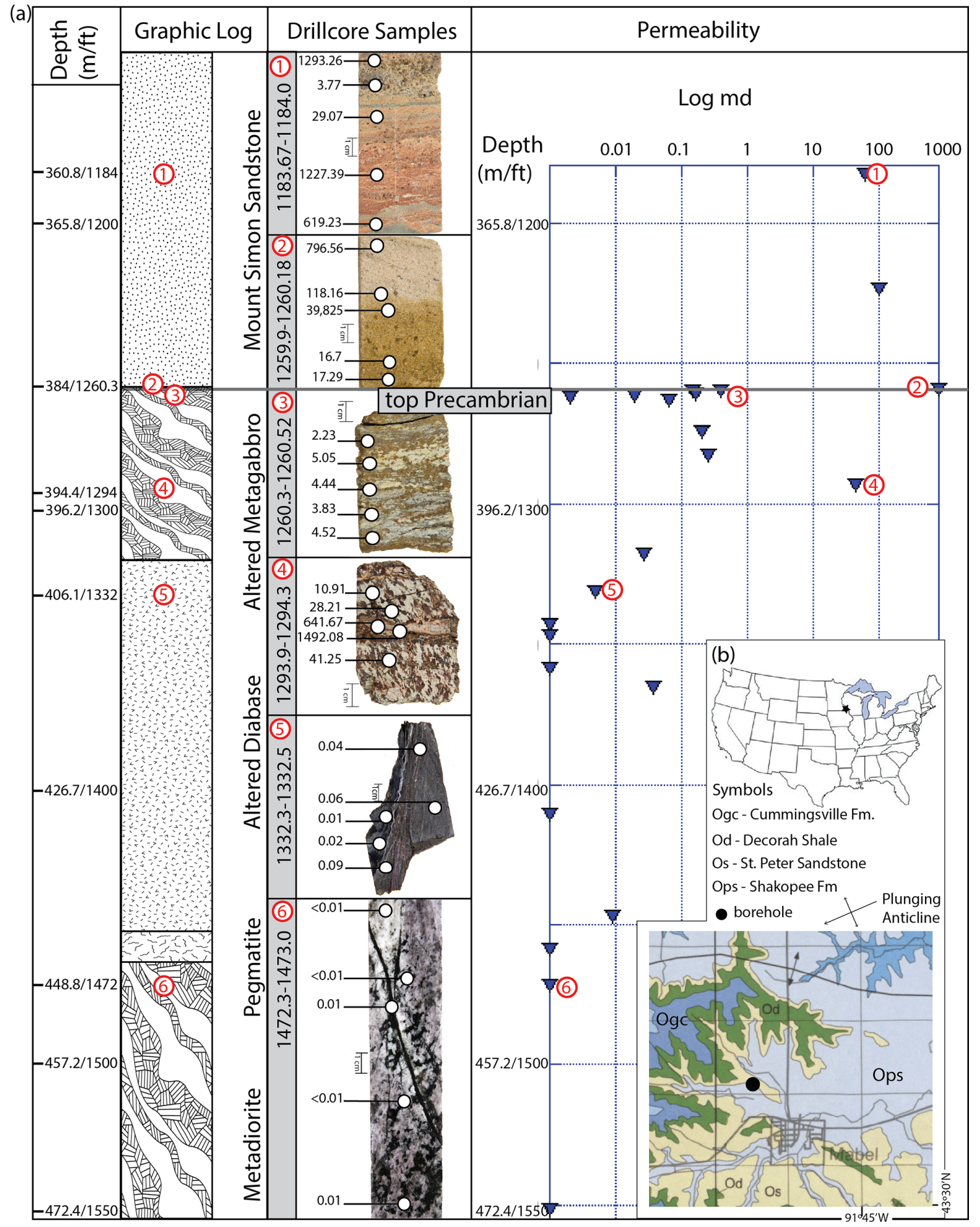

Figure 6. (a) BO-1 lithologic log with select representative core samples of each of the major lithologic units. Above the nonconformity, the analog reservoir, or the injection unit, the Cambrian Mount Simon Sandstone is porous with evidence for both dissolution and oxidation front. The crystalline basement rock consists of foliated, intensely altered, and altered metagabbro with localized faulting, variably altered and faulted diabase localized intrusions, pegmatite dikes, and, at greater depths, relatively unaltered and less-deformed metadiorite. Gas permeability measurements were made on 25 core samples spanning the nonconformity interface. For each core sample tested, five spot measurements were made (locations shown by white circles). For relative comparison across the contact and within the various lithologic units, permeability data (millidarcy, $\mathrm{mD}$ ) are plotted using a log scale and are the averaged values for each sample. (b) Geologic map modified from Mossler et al. (1995). 
well located $150 \mathrm{~m}$ from the fault zone. Wellhead pressures reached over $50 \mathrm{~m}$ excess hydraulic head after $4 \mathrm{~d}$ in response to $5000 \mathrm{~m}^{3} \mathrm{~d}^{-1}$ of continuous injection.

\subsection{Results}

\subsubsection{Lake Superior, Michigan}

Outcrops of the nonconformity between late Proterozoic Jacobsville Sandstone and early Proterozoic altered peridotite crystalline basement are exposed at Presque Isle and Hidden Beach along the southern shore of Lake Superior, Michigan (Fig. 2) (Lewan, 1972). At Presque Isle the topographic relief of the basement nonconformity varies by $2.5 \mathrm{~m}$ over a distance of $1100 \mathrm{~m}$ of outcrop (Cuccio, 2017), is locally cut by small-offset faults $(30 \mathrm{~cm}$ of throw), and is composed of mineralized conglomerate in direct contact with the underlying serpentinized peridotite or is transitionally interbedded with the overlying sandstone (Fig. 2b). Where present, the conglomerate consists of subangular to rounded chalcedony, gneiss, and greenstone cobble clasts with finegrained, poorly sorted, hematite-cemented angular quartz grains.

At Hidden Beach, poorly consolidated basal conglomerates of the Jacobsville Sandstone are in contact with the Precambrian Compeau Creek Gneiss. The quartz arenite consists of fine-grained, angular, moderately sorted quartz with some feldspar. Distinctive bleached open-mode fractures or reduction spots are associated with the lower Jacobsville Sandstone and range in orientation from nearvertical to bedding-parallel. The near-vertical reduction fractures (Fig. 2c) are not observed to extend into the basement.

Optical petrography across the transition from red sandstone protolith to a bleached fracture zone at Hidden Beach reveals a reduction in hematite grain coatings and cements. Whole-rock XRF analysis of the bleached areas of Jacobsville Sandstone indicates a minor depletion of $\mathrm{K}_{2} \mathrm{O}$ and a minor enrichment of $\mathrm{FeO}$ and $\mathrm{MgO}$ relative to the unaltered Jacobsville Sandstone (Fig. 7). At Presque Isle, mineral alteration products in the conglomerate include nontronite, with trace zeolites and iron oxides (Fig. 7). The underlying serpentinized peridotite is black to brown, with abundant white carbonate mesh veinlets and localized stockwork jasperoid veins up to $10 \mathrm{~cm}$ wide (Fig. 2). Jasperoid mineralization occurs along a few small faults that cross the nonconformity (Cuccio, 2017).

\subsubsection{Gallinas Canyon, New Mexico}

Devonian to Mississippian carbonate and clastic rocks of the Espiritu Santo Formation deposited on the Proterozoic quartzo-feldspathic and amphibolitic gneiss, biotite schist, and granitic pegmatite (Lemen et al., 2015) are exposed along a $4 \mathrm{~km}$ long section in Gallinas Canyon, eastern Sangre de Cristo Mountains, New Mexico. The nonconformity is cut by centimeter to meter displacement faults; at this location we characterize both the faulted and un-faulted nonconformity zone (Hesseltine, 2019; Kerner, 2015). The top of the basement is defined by a phyllosilicate-rich zone with variable thickness, 0 to $>5 \mathrm{~m}$, that is truncated by the Del Padre Sandstone. Locally the Del Padre Sandstone is laterally discontinuous (Hesseltine, 2019) but is reported to be up to $15 \mathrm{~m}$ thick, filling depressions in underlying crystalline rock elsewhere in New Mexico (Armstrong and Mamet, 1974). The carbonate and clastic rocks of the Espiritu Santo Formation include $1 \mathrm{~m}$ thick massive, fine-grained, rounded to sub-rounded sandstone with calcite nodules, $\sim 1 \mathrm{~m}$ of microcrystalline dolomite that transitions upward into a chert nodule limestone, interbedded mudstone and limestone, and a massive microcrystalline limestone bed. A phyllosilicaterich zone directly below the nonconformity is approximately $60 \mathrm{~cm}$ thick and is a poorly lithified zone that marks the transition from highly altered (weathering and hydrothermal alteration) to minimally altered crystalline rock (Fig. 8). The Precambrian crystalline rocks are cut by large thrust faults and smaller-scale normal faults (Baltz and Myers, 1999; Lessard and Bejnar, 1976) with some faults juxtaposing sedimentary and crystalline rock (Fig. 8d).

The predominant lithology of the crystalline basement is gneiss, with minor schist, pegmatitic granite, and basalt. Mineral alteration is greatest directly below the nonconformity. This zone is enriched in sericite within feldspars and clay minerals (mixed with hematite and associated with replacement of micas) (Fig. 8). Where cut by faults the nonconformity-associated phyllosilicates form a matrix that surrounds more rigid grains such as quartz, suggesting that deformation in this unit was accommodated by granular flow, a process associated with high pore-fluid pressure (Paterson, 2012). Microscopic fracturing has occurred within the crystalline basement; these fractures are mineralized with iron oxide, sericite, chert, and calcite. The majority of fractures within the crystalline basement occur along weak grains such as sericitized feldspar and altered mica or cut across quartz and feldspar grains. Authigenic calcite is rare within the crystalline basement, though it commonly occurs as coarsely crystalline calcite cement within grain fractures in feldspar and sericitized feldspar

Where faults cut the altered crystalline basement locally, cataclasites are found throughout the fault core. Where faulted, the sedimentary rock damage zone includes large twinned calcite grains in fracture-filling cements and cataclasites that lie along the edges of the calcite veins. The cataclasites include pulverized quartz and feldspar grains, chert, pulverized protolith, and clay- and iron-oxide-rich minerals. Quantitative microprobe analyses of the carbonate and finegrained matrix composition within the sedimentary and basement fault cores reveal that all calcite vein elemental values have a slightly more reduced level of $\mathrm{Fe}$ and $\mathrm{Mg}$ substitution for $\mathrm{Ca}$ than the calcite matrix. The fine-grained matrix within the sedimentary fault core is nearly pure silica, whereas the 


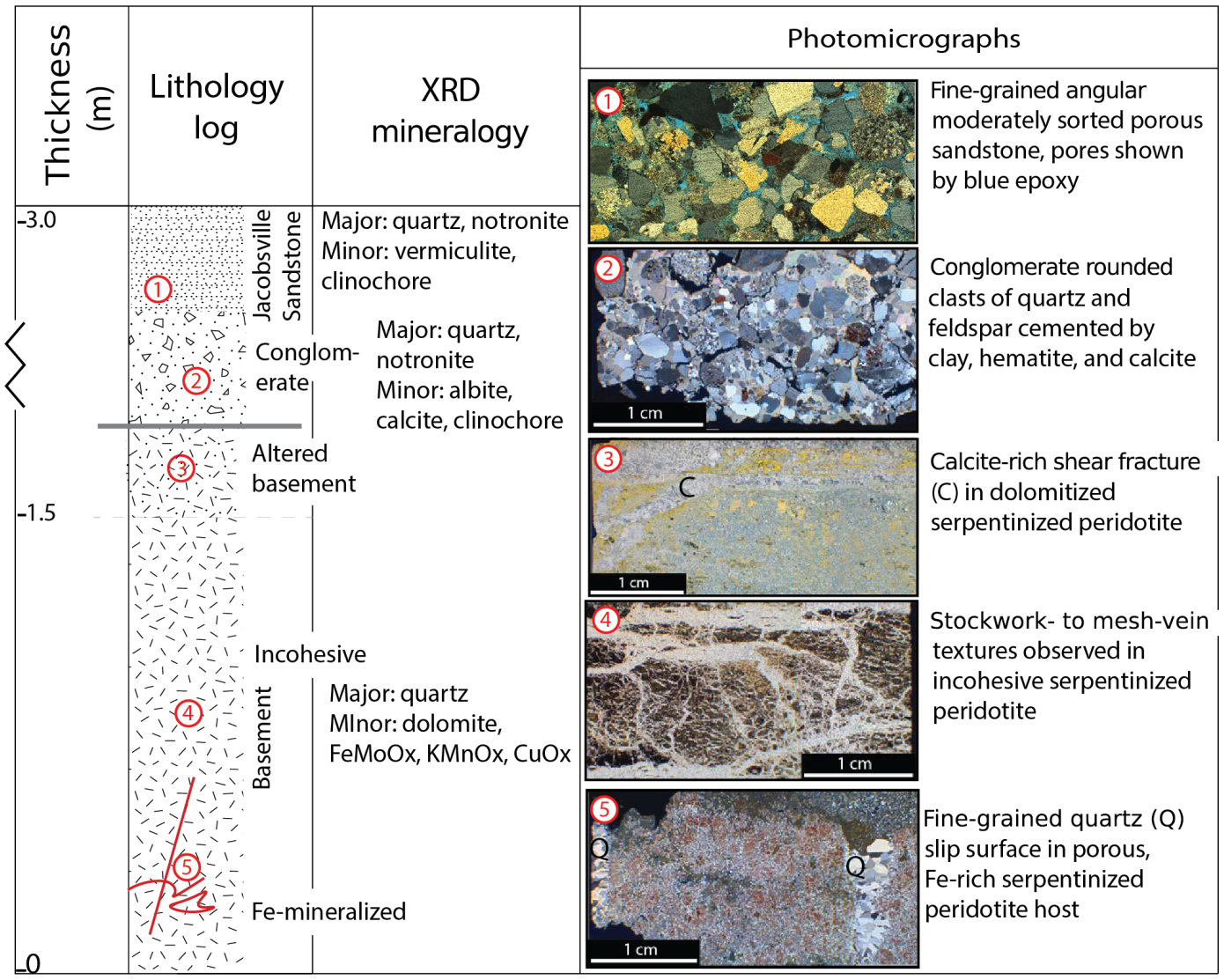

Figure 7. Petrographic summary figure, photomicrographs, and X-ray diffraction results of nonconformity units studied at Presque Isle, Michigan. (a) Jacobsville Sandstone arenite $(100 \times$, ppl), (b) Jacobsville Sandstone altered conglomerate (200×, ppl), (c) basement calciterich slip surface in dolomitized, serpentinized peridotite $(200 \times, \mathrm{xpl}),(\mathbf{d})$ basement serpentinized peridotite $(100 \times$, ppl), (e) basement slip surface within Fe-rich serpentinized peridotite (red) $(100 \times, \mathrm{ppl})$.

fine-grained matrix within the crystalline basement fault core is aluminum-rich (Fig. 8).

\subsubsection{R.C. Taylor 1 Core, Nebraska}

Core from the R.C. Taylor 1 wildcat well was obtained in 1953 in south-central Nebraska (Table S1 in the Supplement). We examined $19.2 \mathrm{~m}$ of core recovered over the Cambrian La Motte Formation sandstone and sheared Proterozoic granitoids in the Central Plains Orogen of the Yavapai province (Marshak et al., 2017; Sims, 1985; Whitmeyer and Karlstrom, 2007). The arkosic La Motte Formation, regionally called the Reagan and Sawatch sandstones, is a finegrained, well-sorted glauconitic sandstone (Fig. 6).

The basal La Motte Formation and uppermost basement are cut by quartz, calcite, dolomite, and iron-oxide veinlets (Fig. 9). Iron-oxide veins cut quartz veins, and both are cut by calcite veins, providing evidence for fracture reactivation (Fig. 9). Below the La Motte Formation is a phyllosilicaterich zone composed of a $40 \mathrm{~cm}$ thick highly altered basement shear zone that overlies a minimally altered basement shear zone; both are comprised of fine crystalline sericitized feldspar and chlorite-rich shear zones and overlie the coarsecrystalline, minimally altered granitic basement containing some sericitized feldspar (Fig. 9).

The altered basement shear zone is composed of quartz, feldspar, biotite, chlorite, and dolomite (Fig. 9). Quartz and feldspars are disintegrated; well-developed chlorite, hematite, and magnetite are altered from biotite, and granular disintegration has resulted in clay development. Open pore space occurs between host-rock grains and neo-formed clays. The basement shear zone is characterized by feldspar, quartz, mica, and the alteration minerals chlorite and dolomite (Fig. 9). The shear zones contain chlorite-lined slip surfaces and $\mathrm{S}-\mathrm{C}$ fabrics within chloritized zones. The shear fabrics are cut by open-mode quartz, sparry calcite, iron-oxide, and dolomite veins. The basal, moderately altered basement unit is a coarse-crystalline granite composed of feldspar, quartz, biotite, and hornblende (Fig. 9). Chlorite is present and associated with minor shear fabrics. Open-mode calcite, dolomite, and quartz veins parallel and cross-cut the chloriterich shear fabrics and cut quartz and feldspar crystals (Fig. 9). In the coarse-crystalline granite, altered feldspars contain 


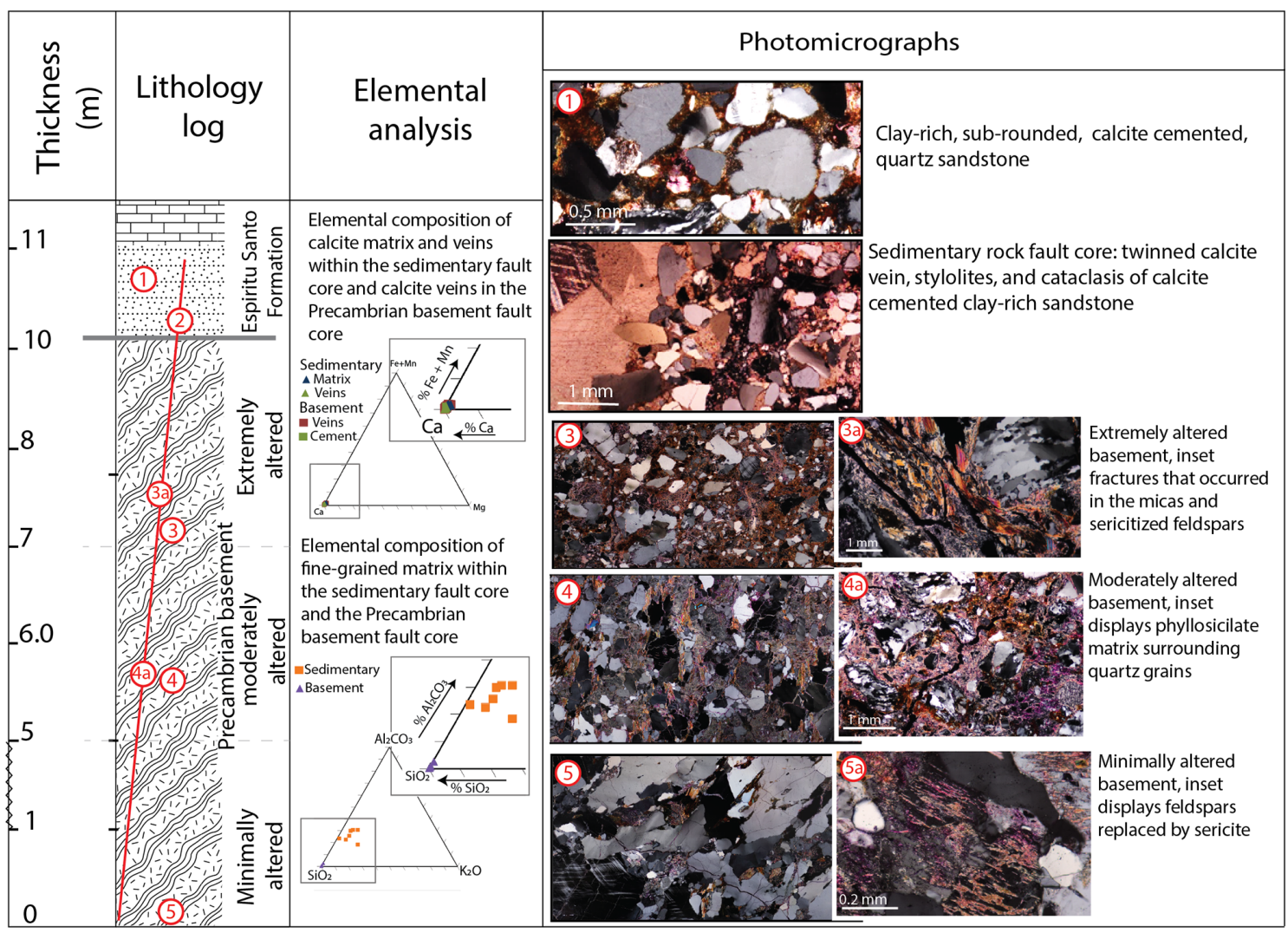

Figure 8. Petrographic and elemental analysis summary of nonconformity units at the Gallinas Canyon site. Thickness is measured in meters from base of outcrop section; the red line represents a fault. Elemental analysis shows a similar calcite composition of the veins within the sedimentary sequence and the Precambrian basement faults. (a, b) The Espiritu Santo sandstones are clay-rich calcite-cemented quartz sandstones; in the fault core, (b) the sandstones are cut by twinned calcite veins and stylolitic textures and contact cataclastic. (c) Adjacent to the nonconformity the granitic basement contain fractures in the micas and sericitized feldspars. (d, e) Basement alteration decreases away from the nonconformity, with a phyllosilicate matrix surrounding quartz grains and sericitization of feldspars occurring $10 \mathrm{~m}$ from the nonconformity.

sericite that has formed adjacent to twin planes. Open-mode fractures mineralized with dolomite, calcite, and hematite occur in the lower $7 \mathrm{~m}$ of the La Motte Formation and are observed through the underlying granitic shear zone covering $12.5 \mathrm{~m}$ of core.

\subsubsection{CPC BD-139 Core, Michigan}

The CPC BD-139 core, obtained in 1964 for the design of a brine disposal well, samples the contact between the Cambrian Mount Simon Sandstone and Precambrian altered granitoid gneiss of the Grenville Front Tectonic Zone (Table S1 in the Supplement). We divide the CPC BD-139 core into three lithologic units: a laminated sandstone, a finely foliated gneiss, and a gneiss with subhorizontal white veins.

Sandstone grains are rounded to sub-rounded and moderately to well-sorted. The Cambrian Mt. Simon Sandstone in the Michigan Basin is characterized as a porous $(5 \%-15 \%$ pore space) arenite to sub-arkosic sandstone (Leeper, 2012). Permeability in the basal Mt. Simon Sandstone is reported to be between $1 \times 10-16$ and $1 \times 10-12 \mathrm{~m}^{2}$ (Frailey et al., 2011).

A discrete boundary separates the Mount Simon Sandstone from the underlying altered granitoid gneiss (Fig. 10). The uppermost $30 \mathrm{~cm}$ of the basement is composed of a tan, fine-grained dolomite horizon that grades into a dark green foliated gneiss cut by pink subvertical fractures over a span of $\sim 5 \mathrm{~cm}$ (Fig. 10). The basal meter of the Mount Simon Sandstone is a tan, finely laminated arenite with minor amounts of iron-rich clay. The quartzo-feldspathic granitoid gneiss near the contact contains the following alteration products: zeolites, vermiculite, $\mathrm{Fe}$ - and $\mathrm{Mn}$-oxides, and carbonates including dolomite (Fig. 10). Dolomitization of the basement host rock reappears $\sim 2 \mathrm{~m}$ below the nonconformity. The original basement foliation is preserved and is associated with micrometer-scale crystalline dolomite grains, radiating silica crystals, and subhorizontal calcite and dolomite openmode veins (Fig. 10). Trace amounts of ankerite, clinochlore, and vermiculite are also present in the dolomitized basement rocks (Fig. 10). 


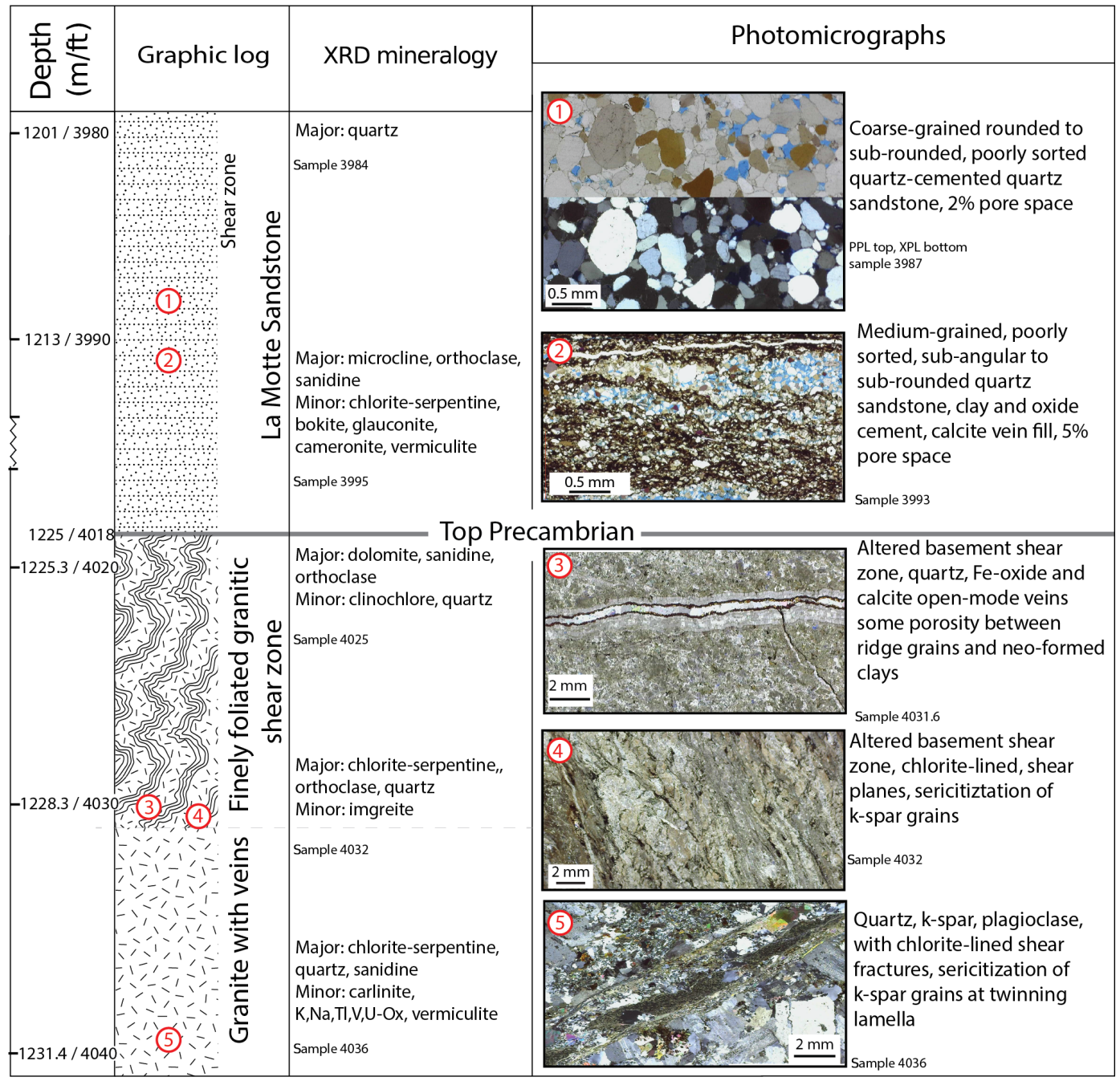

Figure 9. Petrographic summary, photomicrographs, and X-ray diffraction results of nonconformity units studied in the R.C. Taylor 1 core; (a) La Motte Formation sandstone, rounded to sub-rounded, poorly sorted quartz sandstones (100×, ppl and xpl); (b) lower La Motte Formation, opaque Fe-oxide cements and vein fill, porosity shown by blue epoxy, $(100 \times \mathrm{ppl})$; (c) top Precambrian crystalline altered basement shear zone. Syntaxial veins are mineralized with quartz, reactivated, and mineralized with Fe-oxide then sparry calcite. There is some porosity between rigid grains and neo-formed clays $(50 \times$ PPL); (d) altered basement shear zone, chlorite-lined shear planes, sericitization of feldspars along twining lamella $(100 \times \mathrm{ppl})$; (e) coarse-crystalline sericitization of feldspars adjacent to twin lamellae $(150 \times \mathrm{XPL})$.

\subsubsection{BO-1 Core, Minnesota}

The BO-1 core was originally collected in 1962 as part of an exploratory mining project in Fillmore County, southeast Minnesota (Gilbert, 1962) (Table S1 in the Supplement). This core provides a continuous $300 \mathrm{~m}$ section of altered and mineralized rocks of lower Cambrian Mount Simon Sandstone overlying a Precambrian layered intrusive complex of altered and unaltered gabbro, other mafic intrusions, and felsic dikes (Smith et al., 2019; Fig. 11).

Sedimentary sequences in BO- 1 extend to $\sim 1.2 \mathrm{~km}$ where the nonconformity is marked by an approximately $12 \mathrm{~cm}$ zone of pervasive leaching and iron-hydroxide staining (goethite). Intense alteration extends into the basement rocks for $\sim 21 \mathrm{~m}$, with $\sim 50 \mathrm{~m}$ of argillitic and propylitic alteration and/or fracture mineralization observed to $\sim 402 \mathrm{~m}$ of depth (Fig. 11). Localized faults as well as hybrid and openmode fracture surfaces intersect the sampled basement core from within $\sim 1 \mathrm{~cm}$ of the nonconformity contact and extend to $475.5 \mathrm{~m}$; fracture density decreases with depth (Fig. 11). Slip surfaces exhibit oblique to dip-slip slickenlines, range from millimeters to centimeters thick, and are either coated in clay or contain mineral infillings $( \pm$ carbonate, \pm silica, \pm chlorite, \pm iron oxides).

The Mount Simon Sandstone contains a $\sim 0.5 \mathrm{~m}$ zone of intense iron-hydroxide (goethite) alteration at the nonconformity (Fig. 11). This iron-hydroxide oxidized zone extends for several meters into the slightly altered and meta- 


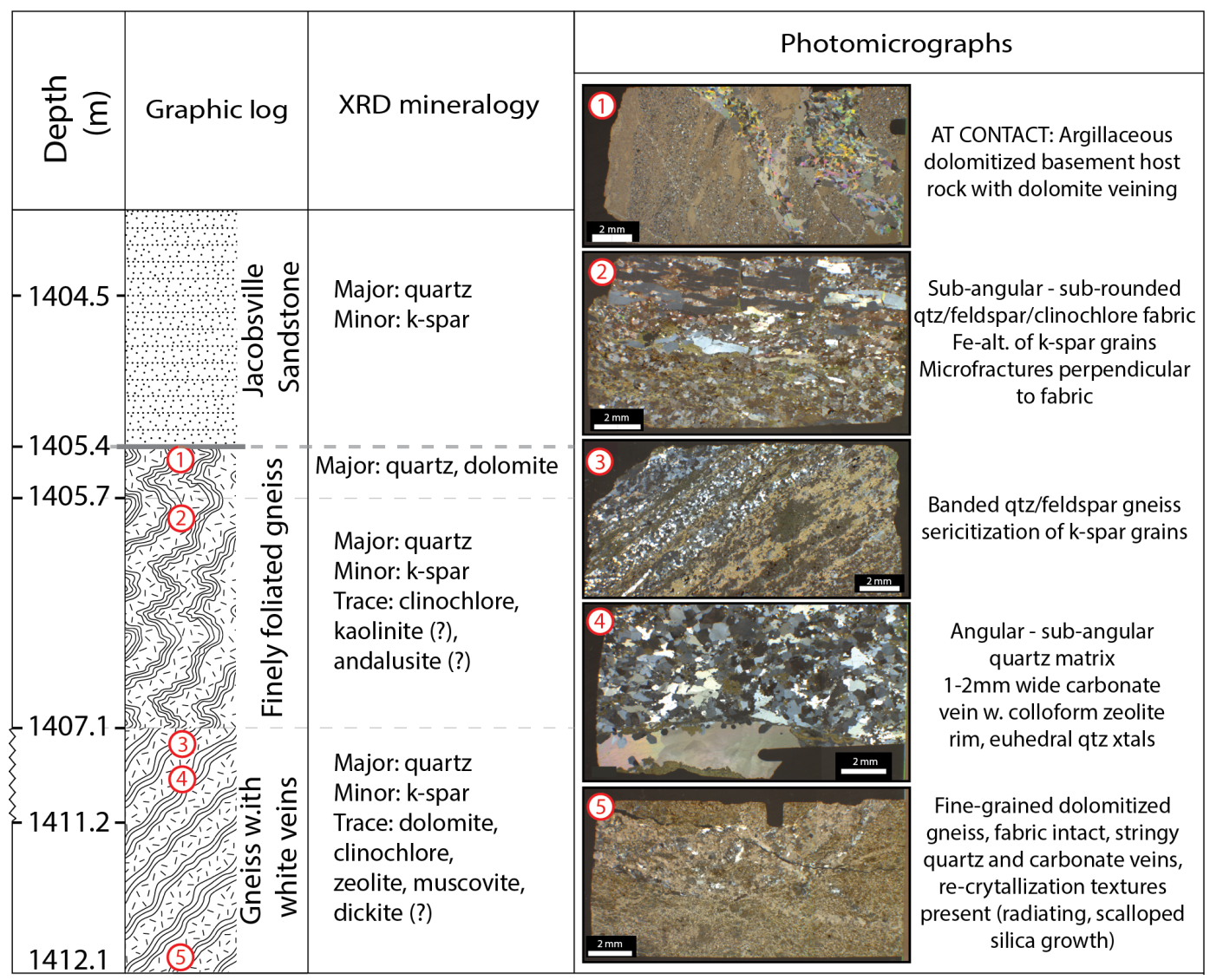

Figure 10. Petrographic summary, depth in meters measured, photomicrographs, and X-ray diffraction results of nonconformity units studied in the CPC BD-139 core. (a) The basement sample at the contact is an argillaceous dolomitized gneiss with dolomite veins (XPL); (b) foliation defined by quartz-feldspar-clinochlore fabric with iron alteration of potassium feldspar grains (XPL); (c) banded quartz-feldspar gneiss with common sericitization of potassium feldspar grains (XPL); (d) carbonate vein with colloform zeolite rim and euhedral quartz crystals (XPL); (e) dolomitized gneiss with common quartz and carbonate veins (XPL).

morphosed crystalline basement rock. From petrographic and XRD analyses, we identify mineralogical assemblages (dolomite, siderite, iron oxides, iron hydroxides, illite, smectite, kaolinite-serpentinite, vermiculite) and textures that are indicative of weathering, diagenesis, and multiple episodes of fluid-rock interactions coupled with deformation within the broad $\sim 50 \mathrm{~m}$ zone of intense alteration also marked by abundant structural discontinuities (fractures, faults, veins) across the nonconformity zone (Fig. 11).

Measured gas permeability values are highest above the nonconformity within the porous Mount Simon sedimentary reservoir (up to $1000 \mathrm{mD}$ ) and vary significantly from 0 to $500 \mathrm{mD}$ below the nonconformity contact. Locally permeability increases in direct correlation with the presence of structural discontinuities (Fig. 6).

\subsection{Hydrogeologic models}

The first model (Fig. 12a) is a Type 0 nonconformity, represented by a sharp contact between the basement and overlying injection reservoir. The second model simula- tion, a Type I nonconformity, includes a $20 \mathrm{~m}$ thick, lowpermeability $\left(k_{x}=k_{z}=3 \times 10^{-18} \mathrm{~m}^{2}\right)$ zone (Fig. $12 \mathrm{~b}$ ); this layer is 1 order of magnitude less permeable than the basement host rock and a further 1 order of magnitude less permeable in the fault core. The continuous low-permeability zone reduces the permeability of the basement fault damage zone by 4 orders of magnitude, making the fault damage zone nonconductive. Pressure does not propagate into the crystalline basement although there was some diffusion of the $2 \mathrm{~m}$ excess hydraulic head front to depths $\leq 500 \mathrm{~m}$. In the third simulation, a discontinuous low-permeability zone is present (Fig. 12c). Where this zone is absent, the pressure front propagates into the basement along the fault damage zone to a depth of $2.5 \mathrm{~km}$. The fault zone was not blocked by the low-permeability zone, and elevated pore pressures propagated downward to depths of $2.5 \mathrm{~km}$ via the fault zone (Fig. 12c). Elevated fluid pressures likewise appeared to be forced down in other areas where the low-permeability zone pinches out, such as towards the right-hand side of Fig. 12c. 


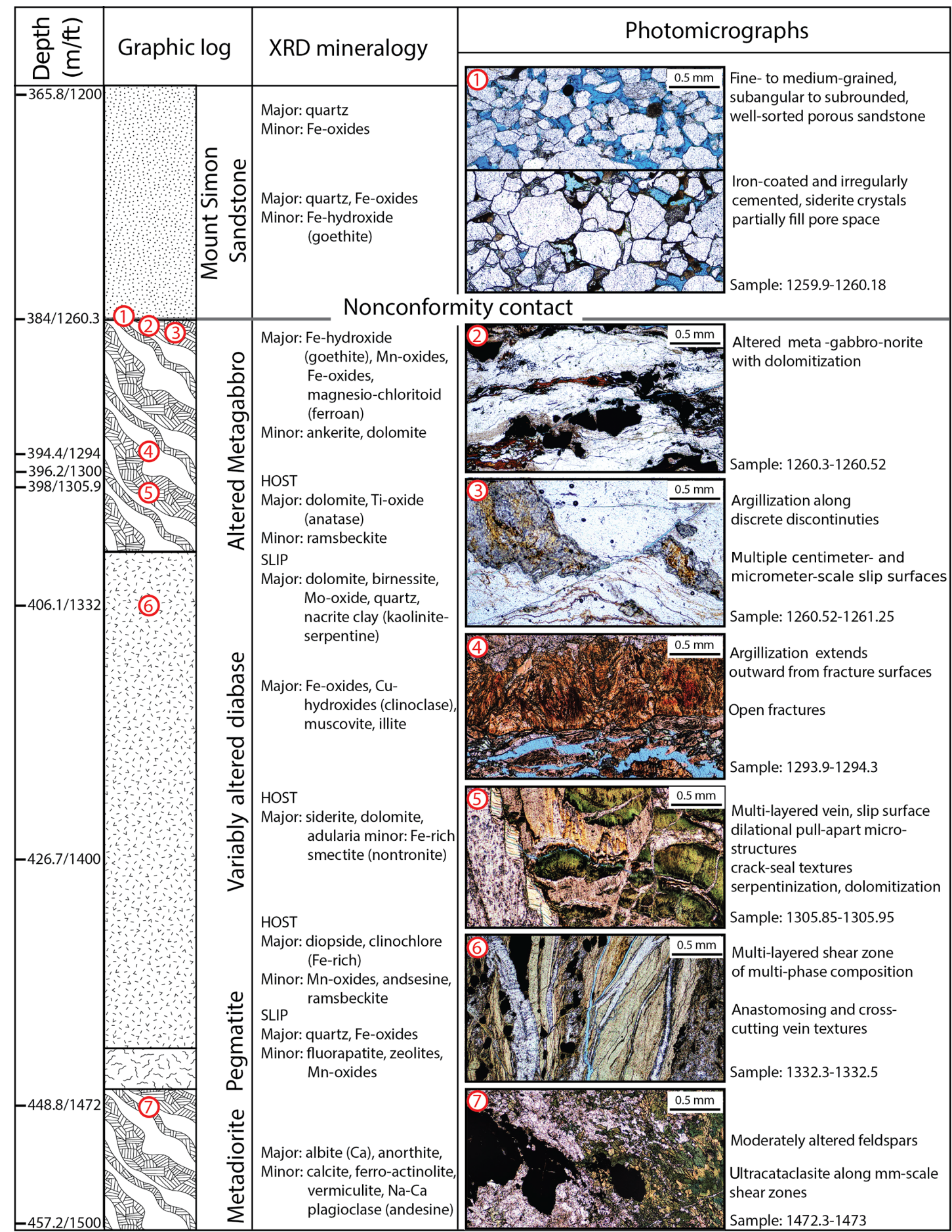

Figure 11. X-ray diffraction mineralogy and photomicrographs of BO-1 drill core samples showing representative compositions and textures across the nonconformity interface contact. Samples within centimeters of the contact (1-3) are strongly weathered, altered, and slightly metamorphosed gabbro-norite. Alteration and diagenesis assemblages include iron-oxide hydroxides with chlorite, ankerite, and dolomite. Alteration extends for $\sim 50 \mathrm{~m}$ into the basement. Sample 3 illustrates millimeter-scale offset across the argillite layer. Note the fracture permeability (blue epoxy) parallel to the slip surface. Fracture surfaces within Sample 4 at $34 \mathrm{~m}$ below the contact are several millimeters of mixed chlorite-clay alteration and fine-scale permeability (blue epoxy). Sample 5 at $1304.9 \mathrm{~m}$ shows multiple phases of fluid-rock interactions coupled with dilation, serpentinization, and dolomitization. There is a multi-layered clay-rich fault core gouge within Sample 6 at $1332 \mathrm{~m}$ or $\sim 70 \mathrm{~m}$ below the contact. Note the open fractures within the central portion of the fault core gouge (blue epoxy). At 1472 or $272 \mathrm{~m}$ below the contact within the meta-grano-diorite unit, clay alteration is observed within feldspar grains at the microscale. 


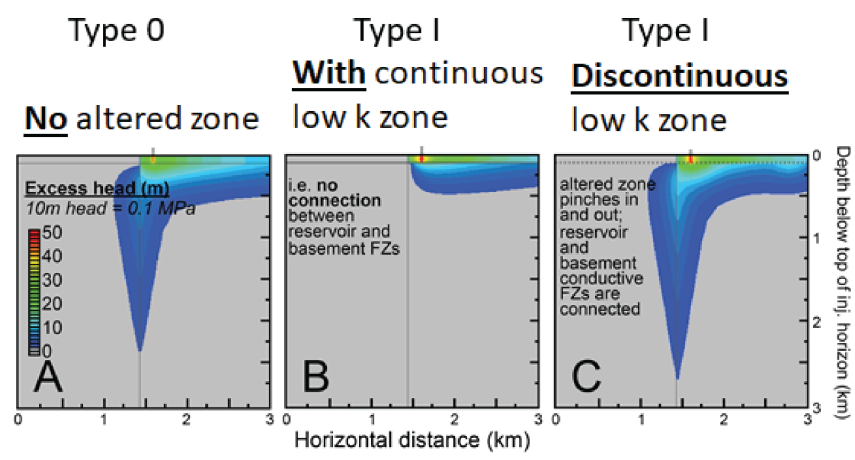

Figure 12. Cross-sectional views of pore pressure envelope propagation resulting from injection into a reservoir underlain by a lowpermeability altered zone. Excess hydraulic heads after 4 years of constant-rate injection are presented for a Paleozoic conduit-barrier fault scenario. (a) Faulted Type 0 nonconformity with no lowpermeability altered zone; (b) Type I nonconformity with an altered zone present as a $20 \mathrm{~m}$ thick confining layer (represented by two horizontal grey lines) that is continuous such that the reservoir and basement fault zones do not connect; (c) Type I nonconformity with a discontinuous altered zone that pinches in and out in $20 \mathrm{~m}$ horizontal intervals (i.e., undulating) but with the reservoir and basement fault zones fully connected. Results are zoomed in to the top $3 \mathrm{~km} \times 3 \mathrm{~km}$ of the model domain. Vertical grey lines indicate the location of the fault zone. The injection well location is indicated on top of each panel. Transition from grey to dark blue (and all subsequent contour lines) denotes a $2 \mathrm{~m}$ increase in hydraulic head (0.02 MPa). Adapted from Ortiz (2017; for details of the modeling approach, see Ortiz et al., 2019).

\section{Discussion}

The nonconformities examined in this study range from sharp contacts to zones several meters thick and exhibit a range of mineralized textures and structural discontinuities (Table S2 in the Supplement). We observe mineralogic alterations across the nonconformity that are expected to impact diffusivity and storativity, and the sites evaluated provide geological and hydrogeological analogs that aid in understanding the impact circulating fluids may have on altering rock properties at depth (Oliver et al., 2006). Based on observations made in this work, we divide nonconformities into three end-member types (Table 1): Type 0 - a sharp contact between sedimentary strata and basement rocks; Type I - an interface dominated by phyllosilicates; and Type II - an interface dominated by non-phyllosilicate secondary mineralization (Table 1). All the nonconformity types observed in this study are cut by structural discontinuities; therefore, several possible contact subtypes exist within these three proposed end-members (Fig. 13). Based on our observations, structural and mineralogical heterogeneities at the sedimentarycrystalline rock nonconformity are thought to control the degree to which fluids, fluid pressure, and associated poroelastic stresses are transmitted over long distances across and along the nonconformity boundary. The structural elements

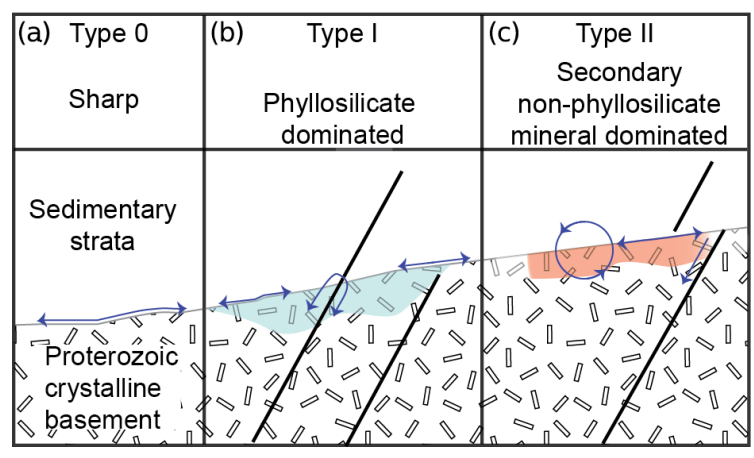

Figure 13. Proposed geologic schematics of the nonconformity contact region. (a) Type 0 - sharp contact expected to prevent direct fluid pressure communication across the contact while promoting migration parallel to the contact distributing fluids laterally. (b) Type I - phyllosilicate-dominated zone above the crystalline basement is expected to inhibit fracture propagation across the nonconformity, prevent fluid migration due to permeability contrast, and promote lateral migration; downward fluid migration can occur at a permeable fault zone. (c) Type II - secondary-mineralizationdominated zone with lateral migration due to permeability contrast; mineralization due to fluid-rock interactions suggests that deep fluid circulation occurs even without enhanced permeability from fractures. All nonconformity types may be cut by structural discontinuities. Blue arrows indicate potential flow paths of injected fluids.

and fluid-related alteration patterns observed in these analog sites support the hypothesis that the nonconformity interface zone influences or controls the potential for cross-contact fluid flow and distribution of fluids within the crust.

Our collective field and core observations in various basement tectonic settings document the occurrence of significant variations in altered or mineralized zones that lead to contrasts in permeability across the nonconformity. Where present, the structural discontinuities include small-offset faults, shear fractures, and veins. In thin section we note evidence for dissolution, recrystallization, new mineral growth, and veins that reflect mineralization or deformation at depth and are not the result of alteration due to weathering alone. Crack-seal textures and calcite twinning lamella suggest vein mineralization at depth (Burkhard, 1993), and the reactivation of preexisting fractures documents episodic fracture growth (Davatzes and Hickman, 2005; Laubach et al., 2004).

At a Type 0 nonconformity, the nonconformity zone is expected to prevent direct fluid pressure communication across the contact due to a significant contrast in rock permeabilities that would hinder cross-contact fluid migration while promoting migration parallel to the contact, distributing fluids laterally away from the injection site (Fig. 13a). At a Type I nonconformity, a phyllosilicate-dominated contact is expected to inhibit fracture propagation across the nonconformity (Ferrill et al., 2012; Larsen et al., 2010; Schöpfer et al., 2006) and therefore maintain a significant permeability contrast, preventing direct fluid migration. In such cases, 
Table 1. Summary of nonconformity types and associated features.

\begin{tabular}{lll}
\hline Nonconformity type & Site location & Summary features \\
\hline Type O & Hidden Beach; Marquette, Michigan & $\begin{array}{l}\text { Sharp, discrete nonconformity contact } \pm \text { topographic } \\
\text { variations between porous sedimentary sequences and } \\
\text { nonporous crystalline basement }\end{array}$ \\
\hline Type I & Gallinas Canyon, New Mexico & $\begin{array}{l}\text { Altered contact with phyllosilicate mineralization; } \\
\text { faults within basement only and/or cross-cutting non- } \\
\text { R.C. Taylor core }\end{array}$ \\
& $\begin{array}{l}\text { conformity contact into overlying sedimentary rocks, } \\
\text { open-mode veins in basement, and overlying sedimen- } \\
\text { tary rocks }\end{array}$ \\
\hline Type II & Presque Isle; Marquette, Michigan & $\begin{array}{l}\text { Altered contact with non-phyllosilicate secondary min- } \\
\text { eralization and hydrothermal mineralization; faults } \\
\text { within basement only and/or cross-cutting nonconfor- } \\
\text { mity contact into overlying sedimentary rocks; open- } \\
\text { BO-1 core }\end{array}$ \\
& $\begin{array}{l}\text { mode and hybrid veins in basement and overlying sedi- } \\
\text { mentary rocks }\end{array}$ \\
&
\end{tabular}

nonconformities result in a poor hydrologic connection between the sedimentary section and deeper basement rocks (Fig. 13b).

However, repeated brittle failure and mineralization, observed in Type I nonconformities, suggest that phyllosilicatedominated shear zones can act as a zone of mechanical weakness that can be reactivated, allowing for the development of fracture permeability. In this fractured nonconformity we observed alteration as deep as $5 \mathrm{~m}$ below the nonconformity in the crystalline rocks examined; however, previous work highlights the potential for fractures and connectivity to basement fault zones at much greater depths (Duffin et al., 1989). Preexisting basement shear zones that are reactivated may allow future fluid circulation during injection scenarios.

Type II nonconformities (Table 1, Fig. 13c, Table S2) are mineralized contacts that include secondary alteration minerals found within $10 \mathrm{~cm}$ to several meters below the nonconformity. The mineralization due to fluid-rock interactions at Type II nonconformities suggests that deep fluid circulation occurs even without enhanced permeability from fractures (Cuccio, 2017) (Fig. 12c). This nonconformity type could prevent brittle deformation but may be more influenced by poroelastic loads. The impact of these contacts on hydrogeologic properties is not yet well-understood or modeled.

The impact the morphology of the nonconformity has on the downward propagation of fluid pressures into the crystalline basement has been shown by several numerical hydrogeologic studies (Ortiz et al., 2019; Segall and Lu, 2015; Yehya et al., 2018; Zhang et al., 2016). Models suggest that direct pore-fluid pressure communication (Ortiz et al., 2019; Segall and Lu, 2015; Yehya et al., 2018) and significant changes in poroelastic stress (Goebel and Brodsky, 2018; Zhang et al., 2016) can occur well way from the injection zones. Numerical models predict that nonconformities with throughgoing fractures distribute fluid deeper into the base- ment rocks and that direct pore pressure communication can destabilize faults at depth (Ortiz et al., 2019; Segall and Lu, 2015; Yehya et al., 2018). All the nonconformity types observed here are cut by structural discontinuities, and several possible contact subtypes exist within these three proposed end-member scenarios (Fig. 12). Fractures, especially fault zones, are expected to distribute fluids and propagate fluid pressures to a greater depth regardless of nonconformity type (Yehya et al., 2018). Because nonconformity interface zones with preexisting deformation fabrics may be preferential flow pathways that distribute fluid pressure away from the injection zone, high-permeability damage zones transmit fluid pressure to greater depths than non-conduit fault zones (Yehya et al., 2018).

To illustrate the effects of reduced permeability above the nonconformity and the impact of permeable fault zones on fluid migration, we compare three models of basal reservoir injection that consider continuous and discontinuous zones of altered low-permeability rocks above the basement (Fig. 12). The Type 0 nonconformity, represented by a sharp contact between the basement and overlying injection reservoir, results in lateral migration away from the injection well and downward migration whereby it encounters a fault zone (Fig. 13a). In the second model simulation, a Type I nonconformity, the presence of a $20 \mathrm{~m}$ thick, low-permeability zone and no connection between basement and sedimentary fault zones result in lateral migration and pressure does not propagate into the crystalline basement (Fig. 12b). The third simulation models a Type I nonconformity with a discontinuous low-permeability zone; where this zone is absent, the pressure front propagates into the basement along the connected fault damage zone to a depth of $2.5 \mathrm{~km}$ and elevated fluid pressures appear to be forced downward where the lowpermeability zone pinches out (Fig. 13c). 
Our collective field and core observations document the occurrence of significant variations in altered or mineralized zones, which would impact permeability values associated with the nonconformity zone, and indicate that alteration coupled with abundant structural discontinuities can result in relatively higher permeability that extends for tens of meters into the crystalline basement rock below the nonconformity.

\section{Conclusions}

We define key rock types and structural elements of the nonconformity zone and split the analog nonconformities into three end-member types. The three nonconformity endmember types provide a broad hierarchy of nonconformities in the midcontinent (Table S1) and are observed at nonconformity sites elsewhere. We expect these nonconformity types to either distribute fluid pressure away from the injection point or provide direct communication with basement rocks, moving fluids to a greater depth across the nonconformity. We observe that fractures cut all nonconformity types and expect in these cases that changes in fluid pressure or poroelastic loads could result in triggered earthquakes within basement rocks (Chang and Segall, 2016; Zhang et al., 2013). Numerical modeling of Type 0 and Type I end-members that include fault zones predicts downward propagation of fluid pressure and changes to poroelastic loads. The data presented here can be used to improve model inputs for evaluation of cross-contact fluid and pressure communication, whether through the creation or modification of existing permeability, poroelastic pathways, or rheological changes associated with fluid-rock interactions. We show that conditions along the nonconformity zone vary, and the data from outcrop and core observations also suggest that injection of brines at depth may drive mineralogical alteration and potential fault zone weakening; these data can also be used to understand the impact that long-term storage of chemically reactive fluids has on rock properties (Callahan et al., 2020). Once fluids penetrate the basement, flow is likely controlled by fracture and fault systems, and the reactivation of preexisting structures is possible. However, microporosity within basement rocks may enhance mineralogical changes over the long term and transmit fluids deeper in the basement while promoting shortterm lateral migration along the nonconformity.

Our observations illustrate that the contact should not be treated as an impermeable barrier to fluid flow nor as one cut by faults of various permeabilities but should instead be evaluated on a site-by-site basis prior to injection of large fluid volumes.

Data availability. Underlying and ongoing research data related to this paper are listed in the Supplement in Table S1. Access to underlying data associated with student theses can be found through university websites: https://digitalcommons.usu.edu/etd/
6889/ (last access: 17 September 2020, Cuccio, 2017) and https:// digitalcommons.usu.edu/etd/7497/ (last access: 17 September 2020, Hesseltine, 2019).

Supplement. The supplement related to this article is available online at: https://doi.org/10.5194/se-11-1803-2020-supplement.

Author contributions. This work was collaborative, and author contributions include but are not limited to the following. ESP collected data and characterized the R.C. Taylor 1 core (Nebraska), conceived and designed the analysis, provided funding support for sample collection and analysis, and wrote the paper. KKB collected field data at the Presque Isle outcrop, conducted data analysis, provided funding support for sample collection and analysis, and wrote the paper. LC collected field data at the Presque Isle outcrop and the CPC BD139 core (Michigan), conducted data analysis, and provided funding support for sample collection. KS collected data from the BO-1 core (Minnesota), conducted data analysis, and provided funding support for sample collection. JPE conceived and designed the analysis, contributed to data analysis and data collection for the CPC BD139 core (Michigan), provided funding support for sample collection and analysis, and wrote the paper. JPO conceived and designed the analysis as well as hydrogeologic modeling based on outcrop and core observations. KK collected and characterized data at the Gallinas Canyon, New Mexico, outcrop. MP contributed analysis tools, conceived and designed the analysis, and conducted hydrogeologic modeling. PM conceived and designed the analysis for Gallinas Canyon, conducted analysis of mineral assemblages and data, and provided funding support for sample collection and analysis.

Competing interests. The authors declare that they have no conflict of interest.

Special issue statement. This article is part of the special issue "Faults, fractures, and fluid flow in the shallow crust". It is not associated with a conference.

Acknowledgements. This work was improved by thoughtful and thorough review, the authors thank the reviewers and Topical Editor, Roger Soliva, for their comments.

Financial support. This work was supported by the collaborative U.S. Geological Survey (USGS) National Earthquake Hazards Reduction Program (NEHRP) (grant nos. G15AP00080 and G15AP00081) through an award to James P. Evans, Kelly K. Bradbury, Mark Person, and Peter Mozley, a Western Colorado University Professional Activity Fund grant to Elizabeth S. Petrie, and a United States Geological Survey-Utah State University cooperative (agreement no. G17AC00345) grant to Kelly K. Bradbury and James P. Evans. Additional student support was obtained from student research grants from the Geological Society of America (GSA) and J.S. Williams Utah State University (USU) Geosciences grants 
awarded to Laura Cuccio and Kayla Smith, the GSA Stephen E. Laubach Structural Diagenesis Award to Kayla Smith, and an Institute of Lake Superior Geology grant to Laura Cuccio.

Review statement. This paper was edited by Roger Soliva and reviewed by Owen Callahan and two anonymous referees.

\section{References}

Abousif, A. M. A.: Mineral and geochemical attributes of the midcontinent rift sequence; An application for deep carbon dioxide sequestration, Ph.D. Dissertation, Colorado School of Mines, Golden, 240 p., 2015.

Anderson, R.: U.S. Geological Survey Airborne Study of Northeast Iowa, Iowa Geological \& Water Survey, available at: https://www.iowadnr.gov/Portals/idnr/uploads/geology/ home/NE_Iowa_mineral_survey.pdf (last access: 20 June 2020), 2012.

Armstrong, A. K. and Mamet, B. L.: Biostratigraphy of the Arroyo Peñasco Group, Lower Carboniferous (Mississippian), northcentral New Mexico, Ghost Ranch N. M. Geol. Soc. Guidebook, 25, 145-158, 1974.

Baltz, E. H. and Myers, D. A.: Stratigraphic framework of upper Paleozoic rocks, southeastern Sangre de Cristo Mountains, New Mexico, with a section on speculations and implications for regional interpretation of Ancestral Rocky Mountains paleotectonics, New Mexico, Bureau of Mines and Mineral Resources Memoir 48, 272 p., Socorro, New Mexico, USA, 1999.

Barnes, D. A., Bacon, D. H., and Kelley, S. R.: Geological sequestration of carbon dioxide in the Cambrian Mount Simon Sandstone: Regional storage capacity, site characterization, and largescale injection feasibility, Michigan Basin, Environ. Geosci., 16, 163-183, 2009.

Burkhard, M.: Calcite twins, their geometry, appearance and significance as stress-strain markers and indicators of tectonic regime: a review, J. Struct. Geol., 15, 351-368, 1993.

Callahan, O. A., Eichhubl, P., Olson, J. E., and Davatzes, N. C.: Experimental investigation of chemically aided fracture growth in silicified fault rocks, Geothermics, 83, 101724, https://doi.org/10.1016/j.geothermics.2019.101724, 2020.

Carr, T. R., Merriam, D. F., and Bartley, J. D.: Use of relational databases to evaluate regional petroleum accumulation, groundwater flow, and $\mathrm{CO}_{2}$ sequestration in Kansas, Am. Assoc. Petr. Geol. B., 89, 1607-1627, 2005.

Chang, K. and Segall, P.: Injection-induced seismicity on basement faults including poroelastic stressing, J. Geophys. Res.-Sol. Ea., 121, 2708-2726, 2016.

Cuccio, L.: Geological Characterization of Precambrian Nonconformities: Implications for Injection-Induced Seismicity in the Midcontinent United States, M.Sc. thesis, Utah State University, Logan, available at: https://digitalcommons.usu.edu/etd/6889/ (last access: 17 September 2020), 2017.

Davatzes, N. C. and Hickman, S.: Controls on fault-hosted fluid flow: Preliminary results from the Coso Geothermal Field, CA, Geoth. Res. T., 29, 343-348, 2005.

Dewers, T., Newell, P., Broome, S., Heath, J., and Bauer, S.: Geomechanical behavior of Cambrian Mount Simon Sandstone reser- voir lithofacies, Iowa Shelf, USA, Int. J. Greenh. Gas Con., 21, 33-48, https://doi.org/10.1016/j.ijggc.2013.11.010, 2014.

Drenth, B. J., Anderson, R. R., Schulz, K. J., Feinberg, J. M., Chandler, V. W., and Cannon, W. F.: What lies beneath: geophysical mapping of a concealed Precambrian intrusive complex along the Iowa-Minnesota border, Can. J. Earth Sci., 52, 279-293, https://doi.org/10.1139/cjes-2014-0178, 2015.

Duffin, M. E., Lee, M., Klein, G. D., and Hay, R. L.: Potassic diagenesis of Cambrian sandstones and Precambrian granitic basement in UPH-3 deep hole, Upper Mississippi Valley, USA, J. Sediment. Res., 59, 848-861, 1989.

Easton, R. M. and Carter, T. R.: Geology of the Precambrian basement beneath the Paleozoic of southwestern Ontario, in: Basement Tectonics 10, edited by: Baars, D. I., Thomas, W. A., Drahovzal, J. A., and Gerhard, L. C., Springer, Netherlands, 221264, 1995.

Ellsworth, W. L., Llenos, A. L., McGarr, A. F., Michael, A. J., Rubinstein, J. L., Mueller, C. S., Petersen, M. D., and Calais, E.: Increasing seismicity in the U.S. midcontinent; implications for earthquake hazard (in Injection-induced seismicity), The Leading Edge, 34, 618-626, 2015.

Everham, W. D. and Huntoon, J. E.: Thermal history of a deep well in the Michigan Basin: Implications for a complex burial history, in: Geothermics in Basin Analysis, edited by: Forster, A. and Merriam, D. F., Springer, New York, 177-202, 1999.

Ferrill, D. A., McGinnis, R. N., Morris, A. P., and Smart, K. J.: Hybrid failure: Field evidence and influence on fault refraction, J. Struct. Geol., 42, 140-150, 2012.

Gair, J.E. and Thaden, R.E.: Geology of the Marquette and Sands Quadrangles, Marquette County, Michigan, Geological Survey Professional Paper 397, available at: https://pubs.usgs.gov/pp/ 0397/report.pdf (last access: 12 June 2020), 1968.

Gilbert, R. C.: Final Report Minnesota Project (Area 4) Fillmore County, Minnesota, The New Jersey Zinc Company, Platteville, Wisconsin, 1962.

Goebel, T. H. W. and Brodsky, E. E.: The spatial footprint of injection wells in a global compilation of induced earthquake sequences, Science, 361, 899-904, 2018.

Harbaugh, A. W. and McDonald, M. G.: Programmer's documentation for MODFLOW-96, an update to the US Geological Survey modular finite-difference ground-water flow model, US Geological Survey, Branch of Information Services [distributor], Reston, Virginia, 1996

Harbaugh, A. W., Banta, E. R., Hill, M. C., and McDonald, M. G.: MODFLOW-2000 , The U.S. Geological Survey modular ground-water model - User guide to modularization concepts and the ground-water flow process, available at: https://water.usgs.gov/nrp/gwsoftware/modflow2000/ MFDOC/index.html?introduction.htm (last access: 12 June 2020), 2000.

Hesseltine, G.: Micro- To Macro-Scale Structural And Lithological Architecture Of Basal Nonconformities: Implications For Fluid Flow And Injection Induced Seismicity, M.Sc. thesis, Utah State University, Logan, available at: https://digitalcommons.usu.edu/ etd/7497/ (last access: 17 September 2020), 2019.

Hoffman, P.: United Plates of America the birth of a craton: Early Proterozoic assembly and growth of Laurentia, Ann. Rev. Earth Pl. Sc., 16, 543-603, 1988. 
Karlstrom, K. E. and Humphreys, E. D.: Persistent influence of Proterozoic accretionary boundaries in the tectonic evolution of southwestern North America: Interaction of cratonic grain and mantle modification events, Rocky Mountain Geology, 33, 161179, 1998.

Keranen, K. M., Savage, H. M., Abers, G. A., and Cochran, E. S.: Potentially induced earthquakes in Oklahoma, USA: Links between wastewater injection and the $2011 \mathrm{Mw} 5.7$ earthquake sequence, Geology, 41, 699-702, 2013.

Keranen, K. M., Weingarten, M., Abers, G. A., Bekins, B. A., and Ge, S.: Sharp increase in central Oklahoma seismicity since 2008 induced by massive wastewater injection, Science, 25, 448-451, 2014.

Kerner, K. R.: Permeability architecture of faulted nonconformities: Implications for induced seismicity, M.Sc. Thesis, New Mexico Institute of Mining and Technology, Socorro, 2015.

Larsen, B., Gudmundsson, A., Grunnaleite, I., Saelen, G., Talbot, M. R., and Buckle, S. J.: Effects of sedimentary interfaces on fracture pattern, linkage, and cluster formation in peritidal carbonate rocks, Mar. Petrol. Geol., 27, 1531-1550, 2010.

Laubach, S. E., Reed, R. M., Olsen, J. E., Lander, R. H., and Bonnell, L. M.: Coevolution of crack-seal texture and fracture porosity in sedimentary rocks: cathodluminescence observations of regional fractures, J. Struct. Geol., 26, 967-982, 2004.

Leeper, N.: Characterization of the Mt. Simon Sandstone in Southwest Ohio for CO2 Sequestration, Senior Thesis, Ohio State University., 44 p., https://kb.osu.edu/handle/1811/520332012 (last access 12 June 2020), 2012.

Leetaru, H. E. and McBride, J. H.: Reservoir uncertainty, Precambrian topography, and carbon sequestration in the Mt. Simon Sandstone, Illinois Basin, Environmental Geosciences, Division of Environmenal Geoscience, American Association of Petroleum Geologists, 16, 235-243, https://doi.org/10.1306/eg.04210909006, 2009.

Leetaru, H. E., Frailey, S., Morse, D., Finley, R. J., Rupp, J. A., Drahozval, J. A., and McBride, J. H.: Carbon sequestration in the Mt. Simon Sandstone saline reservoir, in: Carbon Dioxide Sequestration in Geological Media - State of the Science, edited by: M. Grobe, Pashin, J. C., and Dodge, R. L., American Association of Petroleum Geologists Studies in Geology, Tulsa, OK, USA, 59, 261-277, 2009.

Lemen, D., Lindline, J., and Bosbyshell, H.: The Gallinas Canyon gneiss: a window into the nature and timing of Paleoproterozoic events in Northern New Mexico, in: Guidebook 66 - Geology of the Las Vegas Area, edited by: Lindline, J., Petronis, M., and Zebrowski, J., New Mexico Geological Society 66th Annual Fall Field Conference Guidebook, 312 p., 2015.

Lessard, R. H. and Bejnar, W.: Geology of the Las Vegas area, in: Vermejo Park, edited by: Ewing, R. C. and Kues, B. S., New Mexico Geological Society 27th Annual Fall Field Conference Guidebook, 306 p. 1976.

Lewan, M. D.: Metasomatism and weathering of the Presque Isle serpentinized peridotite, Marquette, Michigan, M.Sc. thesis, Michigan Technological University, Houghton, 1972.

Liu, F., Lu, P., Zhu, C., and Xiao, Y.: Coupled reactive flow and transport modeling of CO2 sequestration in the Mt. Simon sandstone formation, Midwest USA, Int. J. Greenh. Gas Con., 5, 294307, 2011.
Malone, D. H., Stein, C. A., Craddock, J. P., Kley, J., Stein, S., and Malone, J. E.: Maximum depositional age of the Neoproterozoic Jacobsville Sandstone, Michigan: Implications for the evolution of the Midcontinent Rift, Geosphere, 12, 1271-1282, https://doi.org/10.1130/GES01302.1, 2016.

Marshak, S., Domrois, S., Abert, C., Larson, T., Pavlis, G., Hamburger, M., Yang, X., Gilbert, H., and Chen, C.: The basement revealed: Tectonic insight from a digital elevation model of the Great Unconformity, USA cratonic platform, Geology, 45, 391394, https://doi.org/10.1130/G38875.1, 2017.

Miller, T. J.: Evaluation of the Reagan and Lamotte Sandstones in Southwestern Missouri for carbon dioxide sequestration, M.Sc. thesis, Colorado School of Mines, Golden, 221 p., 2012.

Milstein, R. L.: Bedrock geology map of Southern Michigan, State of Michigan, Department of Natural Resources, Lansing, MI, available at: https://ngmdb.usgs.gov/Prodesc/proddesc_ 71887.htm (last access: 12 June 2020), 1987.

Mossler, J. H.: Geologic Atlas of Fillmore County, Minnesota Geological Survey, University of Minnesota, St. Paul, MN, USA, 1995.

Murray, W. E.: Class II Saltwater Disposal for 2009-2014 at the Annual-, State-, and County-Scales by Geologic Zones of Completion, Oklahoma, Oklahoma Geological Survey, Oklahoma, 2015.

Nakai, J. S., Weingarte, M., Sheehan, A. F., Bilek, S. L., and Ge, S.: A possible causative mechanism of Raton Basin, New Mexico and Colorado earthquakes using recent seismicity patterns and pore pressure modeling, J. Geophys. Res.-Sol. Ea., 122, 80518065, https://doi.org/10.1002/2017JB014415, 2017.

Nicholson, C. and Wesson, R. L.: L.: Earthquake Hazard Associated with Deep Well Injection - A Report to the U.S. Environmental Protection Agency, U.S. Geological Survey Bulletin 1951, United States Geological Survey, Alexandria, VA, 1990.

Ojakangas, R. W., Morey, G. B., and Green, J. C.: The Mesoproterozoic Midcontinent Rift System, Lake Superior Region, USA, Sediment. Geol., 141-142, 421-442, 2001.

Oliver, N. H. S., McLellan, J. G., Hobbs, B. E., Cleverly, J. S., Ord, A., and Feltrin, L.: Numerical models of extensional deformation, heat transfer, and fluid flow across basement-cover interfaces during basin-related mineralization, Econ. Geol., 101, 131, 2006.

Ortiz, J. P.: The role of fault-zone architectural elements and basal altered zones on downward pore pressure propagation and induced seismicity in the crystalline basement, New Mexico Institute of Mining and Technology, Socorro, USA, 2017.

Ortiz, J. P., Person, M. A., Mozley, P. S., Evans, J. P., and Bilek, S. L.: The role of fault-zone architectural elements on pore pressure propagation and induced seismicity, Groundwater, 57, 465-478, https://doi.org/10.1111/gwat.12818, 2019.

Paterson, M. S.: Materials science for structural geology, Springer Science \& Business Media, New York, https://doi.org/10.1007/978-94-007-5545-1, 2012.

Petersen, M. D., Mueller, C. S., Moschetti, M. P., Hoover, S. M., Llenos, A. L., Ellsworth, W. L., Michael, A. J., Rubinstein, J. L., McGarr, A. F., and Rukstales, K. S.: One-year seismic hazard forecast for the Central and Eastern United States from induced and natural earthquakes, U.S. Geological Survey Open-File Report 2016-1035, 2016. 
Plains $\mathrm{CO}_{2}$ Reduction (PCOR) Partnership: $\mathrm{CO}_{2}$ Sequestration Projects in Our Region, Energy\&Environmental Research Center, Grand Forks, ND, available at: https://undeerc.org/pcor/ technicalpublications/technicalreports.aspx, last access: 20 June 2020.

Rivers, T.: Lithotectonic elements of the Grenville Province: review and tectonic implications, Precambrian Res., 86, 117-1545, 1997.

Rojstaczer, S. A.: Permeability of continental crust influenced by internal and external forcing, Geofluids, 8, 128-139, 2008.

Rubinstein, J. L., Ellsworth, W. L., McGarr, A., and Benz, H. M.: The 2001-present induced earthquake sequence in the Raton Basin of northern New Mexico and southern Colorado, B. Seismol. Soc. Am., 104, 2162-2181, https://doi.org/10.1785/0120140009, 2014.

Schöpfer, M. P., Childs, C., and Walsh, J. J.: Localisation of normal faults in multilayer sequences, J. Struct. Geol., 28, 816-833, 2006.

Segall, P. and Lu, S.: Injection-induced seismicity: Poroelastic and earthquake nucleation effects, J. Geophys.-Res., 120, 52805103, 2015.

Sims, P. K.: Precambrian Basement Map of the Northern Midcontinent, U.S.A., U.S. Geological Survey Open-File Report Open85-604, United States Geological Survey, Denver, CO, USA, 1985.

Sims, P. K. and Peterman, Z. E.: Early Proterozoic Central Plains orogen a major buried structure in the north-central United States, Geology, 14, 488-491, 1986.

Sloss, L. L.: Sequences in the cratonic interior of North America, GSA Bulletin, 74, 93-114, 1963.

Sloss, L. L.: Forty years of sequence stratigraphy, GSA Bulletin, 100, 1661-1665, 1988.

Smith, K., Paulding, A., Bradbury, K., Potter, K., Evans, J., and Petrie, E.: Geologic Characterization of the Great Unconformity Injection Interface Region from Field and Drillcore Analog Studies: Implications for Midcontinent Induced Seismicity, Geological Society of America Abstracts with Programs v. 51, no. 5, Poster Presentation, https://doi.org/10.1130/abs/2019AM335848, 2019.

St. Onge, M., Van Gool, J., Garde, A., and Scott, D.: Correlation of Archaean and Palaeoproterozoic units between northeastern Canada and western Greenland: constraining the pre-collisional upper plate accretionary history of the Trans-Hudson orogen, in: Earth Accretionary Systems in Space and Time, edited by: Cawood, P. A. and Kroner, A., The Geological Society of London, Special Publications, 318, 193-235, 2009.
Thorleifson, H. (Ed.): Potential Capacity for Geologic Carbon Sequestration in the Midcontinent Rift System in Minnesota, available at: https://files.dnr.state.mn.us/aboutdnr/reports/MGS_ CO2_Report.pdf (last access: 13 June 2020), 2008.

Weingarten, M., Ge, S., Godt, J. W., Bekins, B. A., and Rubinstein, J. L.: High-rate injection is associated with the increase in U.S. mid-continent seismicity, Science, 248, 1336-1340, 2015.

Whitmeyer, S. J. and Karlstrom, K. E.: Tectonic model for the Proterozoic growth of North America, Geosphere, 3, 220-259, 2007.

Wickstrom, L. H., Venteris, E. R., Harper, J. A., McDonald, J., Slucher, E. R., Carter, K. M., Greb, S. F., Wells, J. G., Harrisson III, W. B., Nuttall, B. C., Riley, R. A., Drahovzal, J. A., Rupp, J. A., Avary, K. L., Lanham, S., Barnes, D. A., Gupta, N., Baranoski, M. A., Radhakkrishnan, P., Solis, M. P., Baum, G. R., Hohn, M. E., Parris, M. P., McCoy, K., Grammer, G. M., Pool, S., Luckhardt, C., and Kish, P.: Characterization of Geologic Sequestration Opportunities in the MRCSP Region, available at: https://www.researchgate.net/profile/Larry_Wickstrom/ publication/292983481_292983481_Characterization_of_ Geologic_Sequestration_Opportunities_in_the_MRCSP_ Region/links/56b3b4f008ae636a540d1bfb/Characterization-ofGeologic-Sequestration-Opportunities-in-the_MRCSP_Region/ links/56b3b4f008ae636a540d1bfb/Characterization-ofGeologic-Sequestration-Opportunities-in-the-MRCSPRegion.pdf (last access: 12 June 2020), 2010.

Yehya, A., Yang, Z., and Rice, J. R.: Effect of fault architecture and permeability evolution on response to fluid injection, J. Geophys. Res.-Sol. Ea., 123, 9982-9987, https://doi.org/10.1029/2018JB016550, 2018.

Zhang, Y., Person, M., Rupp, J., Ellett, K., Celia, M. A., Gable, C., Bowen, B., Evans, J., Bandilla, K., Mozley, P., Dewers, T., and Elliot, T.: Hydrogeologic Controls on Induced Seismicity in Crystalline Basement Rocks Due to Fluid Injection into Basal Reservoirs, Groundwater, 51, 525-538, https://doi.org/10.1111/gwat.12071, 2013.

Zhang, Y., Edel, S. S., Pepin, J., Person, M., Broadhead, R., Ortiz, J. P., Bilek, S. L., Mozley, P., and Evans, J. P.: Exploring the potential linkages between oil-field brine reinjection, crystalline basement permeability, and triggered seismicity for the Dagger Draw Oil field, southeastern New Mexico, USA, using hydrologic modelling, Geofluids, 16, 971-987, 2016. 